FIU Law Review

Volume 4 | Number 2

Article 8

Spring 2009

\title{
Gay and Lesbian Parenting in Florida: Family Creation Around the Law
}

Rebecca Mae Solokar

Follow this and additional works at: https://ecollections.law.fiu.edu/lawreview

Part of the Other Law Commons

Online ISSN: 2643-7759

\section{Recommended Citation}

Rebecca M. Solokar, Gay and Lesbian Parenting in Florida: Family Creation Around the Law, 4 FIU L. Rev. 473 (2009).

DOI: https://dx.doi.org/10.25148/lawrev.4.2.8

This Article is brought to you for free and open access by eCollections. It has been accepted for inclusion in FIU Law Review by an authorized editor of eCollections. For more information, please contact lisdavis@fiu.edu. 


\title{
Gay and Lesbian Parenting in Florida: Family Creation Around the Law
}

\author{
Rebecca Mae Salokar ${ }^{*}$
}

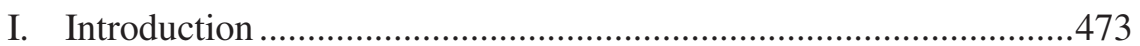

II. Historical Background..............................................................476

III. Creating Lesbigay Families in Florida .........................................482

A. Single-Parent Adoption ...........................................................483

1. "Homosexual" Defined ...................................................484

2. Statute of Repose .........................................................489

B. Artificial Insemination ........................................................492

C. Surrogacy .......................................................................498

1. Traditional Surrogacy ......................................................500

2. Gestational Surrogacy ...................................................502

a. Gestational Surrogacy Defaults: Whither the Law? .......504

b. Establishing Paternity.................................................506

c. Dis-establishing Maternity ............................................509

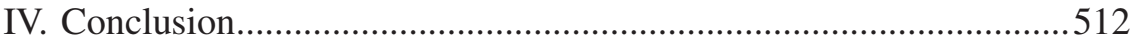

\section{INTRODUCTION}

No longer is it true that a woman who gives birth to a child is that child's biological mother. The biological mother may well be standing at the side of the woman as she gives birth, coaching her lesbian partner through the birth of their first child. In another hospital room, twin boys born to a woman may be half-brothers, but not her sons. Instead, the two men standing just outside the birthing room--a gay couple--are each the biological father to one of the boys, but the children share a common biological mother who remains an anonymous egg donor in a gestational surrogacy arrangement. The medical wonders described above are the result

B.A. Florida International University, 1981; M.A. Syracuse University, 1982; Ph.D. Syracuse University, 1988; J.D. Candidate, Florida International University School of Law, 2009. I would like to thank Professors M.C. Mirow and Robert J. Levy for sparking my interest in the legal matters of all families and for their encouragement on this project. My special thanks goes to Elizabeth F. Schwartz, Esq., whose daily grind in fashioning family creation and protection in South Florida will provide continuing grist for my intellectual mill. 
of readily accessible scientific reproductive technologies that continue to evolve.

Over the past twenty years, these reproductive techniques have not only become more accessible, they are also increasingly used by unmarried persons and couples to create families that do not conform to society's traditional and legal conceptions of "family." "The nuclear family of two, opposite-sex parents, and their shared biological offspring has been joined by families headed by same-sex couples or single parents. ${ }^{3}$ These scientifically-spawned, non-traditional families emerged in the wake of a national transformation in divorce laws and a relatively rapid evolution in gender expectations with respect to work and home, trends that began in the 1960s. ${ }^{4}$ Data from the 2000 Census indicates a continuing decline in the proportion of American households headed by opposite-sex married couples and a corresponding growth in households headed by single women or men, and unmarried couples. ${ }^{5}$ Buried in these statistical trends is a growing awareness of a "gayby" boom, an era in which gay men and lesbians, both as individuals and as couples, are increasingly choosing to become parents and establish families of their own. ${ }^{6}$ Scientific developments in reproductive technologies ranging from sperm banks and artificial insemination to in

1 Consider, for example, the development of tri-gametic in-vitro fertilization where the only genetic material used in conception is obtained from the eggs of two different women. The DNA from the non-gestational woman is removed from her egg and placed in a sperm casing, which has been stripped of its donor's DNA. The reconstituted "sperm" is then used to fertilize the gestational mother's egg. Kyle C. Velte, Egging on Lesbian Maternity: The Legal Implication of Tri-Gametic In Vitro Fertilization, 7 AM. U. J. GENDER SOC. POL'Y \& L. 431, 433-34, n. 11 (1999). There may be some legal limits to some reproductive techniques that do not use a sperm cell. Michelle M. Hausmann, Surrogacy and Related Matters, in AdOPTION, PATERnity, AND Other Florida FAMILY PRACTICE $\$ 9.19$ (The Florida Bar, 2007).

2 See John A. Robertson, Assisted Reproductive Technology and the Family, 47 HASTINGS L.J. 911, 912 (1996) (discussing various reproductive techniques).

3 Craig W. Christensen, Legal Ordering of Family Values: The Case of Gay and Lesbian Families, 18 CARDOZO L. REV. 1299, 1331 (1997) (defining the nuclear family).

4 See generally LaWrence W. WAGgOner, Gregory S. AleXANDER, Mary Louise Fellows \& Thomas P. Gallanis, Family Property Law: Cases and Materials on Wills, Trusts, and FUTURE INTERESTS 1-4 (4th ed. 2006).

5 Tavia Simmons \& Martin O'Connell, U.S. Census Bureau, Married-Couple and UnmarriedPartner Households: 2000, (No. CENSR-5) 3 (2001), available at http://www.census.gov/prod/ 2003pubs/censr-5.pdf. See also T.P. Gallanis, Inheritance Rights for Domestic Partners, 79 TuL. L. REV. 55, 57-59 (2004) (reporting additional census data on unmarried couples).

6 The earliest use of the term, "gayby boom," may have appeared in Eloise Salholz et al., The Future of Gay America, NewsweEK, Mar. 12, 1990, at 20. See Mary Patricia Byrn, From Right To Wrong: A Critique Of The 2000 Uniform Parentage Act, 16 UCLA WOMEN's L.J. 163, 209-15 (2007), and Melanie B. Jacobs, Micah Has One Mommy And One Legal Stranger: Adjudicating Maternity For Nonbiological Lesbian Coparents, 50 BUFF. L. REV. 341, 342 (2002) for statistical references on the gayby boom. While there is no certainty in the numbers of gay men and lesbians raising children, there is consensus that the numbers are increasing. See Lynn D. Wardle, A Critical Analysis of Interstate Recognition of Lesbigay Adoptions, 3 AVE MARIA L. REV. 561-63 nn.2-7 (2005) (suggesting that statistics offered by proponents of lesbigay adoptions are inflated while acknowledging dramatic increases in numbers). 
vitro fertilization and gestational surrogacy are making "lesbigay" family creation even easier.

Innovation in family creation may have roots in science, but the implications for law are especially significant when one recognizes the importance that family plays in the American legal landscape. The right to "establish a home and bring up children" has long been posited as a liberty afforded to individuals by the U.S. Constitution under the Fifth and Fourteenth Amendments. " The concept of "family" underpins our legal notions of privacy, ${ }^{8}$ property, ${ }^{9}$ and inheritance. ${ }^{10}$ In many states, the law has slowly evolved to embrace the modernization of the American family that has resulted from both the societal changes in family relationships as well as advances in science. ${ }^{11}$ However, some states continue to resist legal recognition of non-traditional families by either limiting or simply barring a range of family arrangements. ${ }^{12}$

Florida is one state that has made family creation particularly difficult for gay men and lesbians. In 1977, the state statutorily banned adoptions by

7 Meyer v. Nebraska, 262 U.S. 390, 398 (1923) (finding that liberty encompasses the right to marry, establish a home and bring up children); Pierce v. Soc'y of Sisters, 268 U.S. 510, 534-35 (1925) (finding parental liberty violated by state law mandating public school attendance). But see Lofton v. Sec'y of Dept. of Children \& Family Servs., 358 F.3d 804 (11th Cir. 2004) (finding that familial rights only accrue to legally-recognized families).

8 See, e.g., Griswold v. Connecticut, 381 U.S. 479, 485-86 (1965) (recognizing a right to privacy in marital reproductive decisions).

9 See generally Leslie JoAn Harris, Lee F. Teitelbaum \& June Carbone, Family Law 34111 (3d ed. 2005).

10 Consider the range of state laws providing for spousal elections against a will, rights of heirs under intestacy statutes, and homestead provisions. See, e.g., FLA. STAT. § 732.201 (2006) (granting surviving spouse elective share of decedent's estate); FLA. STAT. § 732.102-103 (2006) (granting spouse and heirs intestate share of estate); and FLA. STAT. $§ 732.401-403$ (2006) (providing spouse and lineal descendants protections of homestead property).

11 See, e.g., Sharon S. v. Superior Court, 73 P.3d 554, 571 (Cal. 2003); Adoptions of B.L.V.B. and E.L.V.B., 628 A.2d 1271 (Vt. 1993); and Adoption of Tammy, 619 N.E.2d 315 (Mass. 1993) (recognizing second-parent adoptions in cases of lesbian couples using artificial insemination); and In re Jacob, 660 N.E.2d 397 (N.Y. 1995) (recognizing second-parent adoptions by unmarried partners of biological mothers in two cases, one a same-sex partner where child was conceived using artificial insemination, and an opposite-sex partner where the child was conceived in previous marriage and biological father consented to the adoption).

12 Examples abound. Consider the various bans on civil unions and same-sex marriages found in state constitutions and state statutes, and in some cases, further language that limits certain rights only to married couples. There are also restrictions on who may adopt and foster parent, limitations on visitation orders, child custody awards, and the regulation or outright prohibition of surrogacy agreements. Current data on these policies are readily available from the National Gay and Lesbian Task Force, Research \& Reports, http://www.thetaskforce.org/reports_and_research.

In 1996, the national government weighed in on family issues by adopting the Defense of Marriage Act, which limits the federal government's recognition of marriage to a "legal union" between a man and a woman as husband and wife, and permits states to deny recognition of marriages performed legally in other states between same-sex couples. Pub. L. No. 104-199, 110 Stat. 2419 (1996) (codified at 1 U.S.C. $\$ 7$, and 28 U.S.C. $§ 1738 C$ ). 
"homosexuals,"13 and despite numerous legal challenges, the ban remains in force. $^{14}$ This Comment explores how gay men and lesbians in Florida have managed to build their families despite the ban, and considers the implications of these new family structures for Florida's laws and public policies. Following a review of the historical events leading up to Florida's ban on adoptions by homosexuals and subsequent efforts to overturn it, legal avenues of family creation available to lesbigay parents in Florida are described. Potential legal challenges are explored and discussed, drawing on litigation in Florida, other states, and federal courts. Pending legislation and avenues for policy change are also considered.

\section{HISTORICAL BACKGROUND}

Florida's statutory ban on adoptions by "homosexuals" has its roots in the backlash to what has been described as the third wave of the American gay liberation movement. ${ }^{15}$ In the wake of the Stonewall riots of 1969, gay and lesbian interest groups formed in major cities across the country to work for legal and political change. ${ }^{16}$ High on their agenda was ending

13 "Homosexual" is the term employed in the statute, however, the statute failed to define "homosexual." FLA. STAT. § 63.042(3) (2006). As a result, the Florida Supreme Court adopted a conductbased definition, rather than an orientation or identity characterization of "homosexual." See infra text accompanying notes 60-89.

14 See Lofton v. Sec'y of Dep't. of Children \& Family Servs., 358 F.3d 804 (11th Cir. 2004); Florida Dep't. of Health \& Rehab. Servs. v. Cox, 627 So. 2d 1210 (Fla, 2d Dist. Ct. App. 1993); Seebol v. Farie, 16 Fla. L. Weekly C52 (16th Cir. Ct. Mar. 15, 1991), reprinted in Florida Dep't of Health \& Rehab. Servs. v. Cox, 627 So. $2 d$ at 1221-29. No other state has an outright ban on adoptions by homosexual persons. Mississippi bars adoption by couples of the same gender, but would permit an adoption by a single homosexual. MISS. CODE. ANN. § 93-17-3(5). Alabama's legislature adopted a joint resolution to express its intent, "to prohibit child adoption by homosexual couples." See Code Commissioner's Notes, ALA. CODE § 26-10A-6 (2006), citing Act 98-439 (HJR 35). Utah bans adoptions by a person who is "cohabiting" with another in a non-marital, sexual relationship, but would apparently not bar an adoption by a non-cohabitating, single homosexual. UTAH CODE ANN. § 78-30-1(3)(b) (2006). Michigan, which permits adoption by one member of a same-sex couple, will not permit adoptions by a same-sex couple legally married in another state. Mich. Op. Att'y. Gen. 7160 (2004), 2004 WL 2096457. In 1995, Nebraska's Department of Social Services barred adoption by individuals "who are known by the agency to be homosexual or who are unmarried and living with another adult" by policy directive. Memorandum from Director, Nebraska Department of Social Services on Placement in Foster Care to District and Division Administrators, \#1-95 (January 23, 1995), available at http://www.hhs.state.ne.us/jus/memos/ AM-1.pdf.

15 The gay and lesbian movement has been described in three eras. The first period, homosexual emancipation, began in the 1890s and lasted until World War II. The second period, marking the homophile movement, followed the war through the Stonewall Riots of 1969 . The modern era of gay and lesbian liberation began in the 1970s and continues today. MARGARET CRUIKSHANK, THE GAY AND LESBIAN MOVEMENT 63 (1992). On the backlash effect, see JAMES W. ButTON, BARBARA A. RiENZ AND KenNeth WalK, PRIVATE Lives, Public Conflicts 68-69 (1997).

16 The Stonewall Riots occurred in New York City at the Stonewall Bar when police officers attempted to conduct a vice operation, a form of harassment employed against cross-dressers and gay men. The violence and civil disobedience that resulted lasted several days, and marked the beginning of the modern gay liberation era. See CrUIKSHANK, supra note 15, at 63. 
discrimination, and gay activists saw some early successes. ${ }^{17}$ In South Florida, activists organized and effectively persuaded the Dade County (now, Miami-Dade) Commission to adopt a human rights ordinance that would have outlawed discrimination in areas like employment, housing, and private education. $^{18}$ Although passed by a 5-3 vote on January 19, 1977, a petition drive led by entertainer Anita Bryant secured sufficient signatures to force the commission to either repeal the ordinance itself or submit it to the electorate for a referendum vote. ${ }^{19}$ In April, the commission voted to put the issue to the voters at a special election in June of that year. ${ }^{20}$ A bitter, and at times, violent campaign resulted in the repeal of the ordinance by better than a two-to-one margin. ${ }^{2}$

Despite its local character, the petition drive and high-profile campaign merited state-wide and national attention. Then-governor Reuben Askew spoke out against the ordinance. ${ }^{22}$ In the state legislature, Senator Alan Trask from Winter Haven introduced two bills. ${ }^{23}$ One amended the state's marriage license laws, requiring that one party be male, and the other party be female. $^{24}$ The other added a single sentence to the adoption laws:

17 Thirty-six cities had adopted non-discrimination ordinances by early 1977. Adon Taft and Susan Burnside, Group Opposes Proposed Metro Law: Gay Anti-Bias Bill Criticized, MiAmi HeraLD, Jan. 17, 1977, at B1.

18 Theodore Stanger, Dade Approves Ordinance Banning Bias Against Gays, MiAmi HeraLD, Jan. 19, 1977, at A1.

19 John Arnold, Ruvin Swing Vote May Throw Gay-Rights Issue to Voters, MiAMI HeRALD, Apr. 17, 1977, at A1.

20 John Arnold, Dade Will be Gay-Rights Battlefield, Miami Herald, Apr. 20, 1977, at A1.

21 Allan H. Terl, An Essay on the History of Lesbian and Gay Rights in Florida, 24 NovA L. REV. 793, 805 (2000). Some 21 years later, in 1998, Miami-Dade County finally adopted a Human Rights Ordinance that bans discrimination on the basis of sexual orientation, real or perceived, in housing, finance, employment and public accommodations. Miami-Dade County Ord. No. 98-170, § 1, Dec. 1, 1998, codified at Chap. 11A, Art. 1, § 11A-1 (2007), available at http://www.municode.com/resources/ gateway.asp?pid $=10620 \&$ sid $=9$.

22 Robert Hooker, Askew Would Vote 'No' on Gay Rights: Miami Gays Seethe, Miami Herald, Apr. 17, 1977, at D2.

23 Democrat, Winter Haven. Terl, supra note 21, at 806.

24 Ch. 77-139, § 1, 1977 Fla. Laws 465 (codified at FLA. STAT. § 741.07 (1977)). As this Comment is written, Florida faces yet another battle over gay rights. In January 2008, the Secretary of State certified that the requisite signatures had been gathered through the initiative process to place a constitutional amendment on marriage on the November 2008 ballot. The proposed amendment states, "Inasmuch as marriage is the legal union of only one man and one woman as husband and wife, no other legal union that is treated as marriage or the substantial equivalent thereof shall be valid or recognized." Cited in Advisory Opinion to the Attorney General Re Florida Marriage Protection Amendment, 926 So. 2d 1229, 1232 (Fla. 2006).

If adopted by $60 \%$ of the voters, the amendment would effectively impose a constitutional bar on Florida's recognition of out-of-state gay marriages and civil unions, would probably undermine domestic partnerships currently recognized in several counties and municipalities across the state, and may even jeopardize some contractual arrangements between unmarried couples, regardless of whether they are of opposite sexes or the same sex, according to organizations campaigning against the amendment. See, e.g., SAVE-Dade, Marriage Amendment,http://savedade.readyhosting.com/marriage_ 
"No person eligible to adopt under this statute may adopt, if that person is a homosexual." ${ }^{25}$ Both bills passed the state legislature and were signed into law by Governor Askew two days after the Dade County referendum vote. ${ }^{26}$

The adoption ban remained settled law in Florida during the 1980s as the state's gay community recovered from the Dade referendum fight, focused its attention on the outbreak of AIDS, and sought out allies in its efforts to end discrimination. ${ }^{27}$ In 1989, the American Civil Liberties Union (ACLU) of Florida made overturning the adoption ban one of its litigation priorities and filed the first legal challenge to the law in Monroe County (the Florida Keys). ${ }^{28}$ Ed Seebol, a gay man whose application to adopt was rejected by the Department of Health and Rehabilitative Services because he indicated that he was "homosexual," claimed that the adoption ban was unconstitutional under state law. ${ }^{29}$ The State made no appearance to defend against the suit. ${ }^{30}$ Seebol and the ACLU prevailed when the court ruled that the adoption ban violated Seebol's right to privacy, due process rights, and equal protection under both the state and national constitutions. Because the State filed no appeal challenging the trial court's decision, the statutory ban on gay adoptions effectively had no legal force in Monroe County. ${ }^{31}$

Following this early success, the ACLU filed a second case in Sarasota County on behalf of two gay men who were denied the opportunity to adopt

amendment.htm; Florida Red and Blue, http://www.floridaredandblue.com/; and Fairness for All Families-Vote NO Florida, http://www.fairnessforallfamilies.org/.

25 Ch. 77-140, § 1, 1977 Fla. Laws 466 (codified at Fla. STAT. § 63.042 (1977)).

26 Id; Ch. 77-139, § 1, 1977 Fla. Laws 465 (codified at FlA. STAT. § 741.04(1) (1977)). For comments by state senators during legislative consideration of $\S 63.042(3)$, see Tiffani G. Lee, Case Note, Cox v. Department of Health and Rehabilitative Services: A Challenge to Florida's Homosexual Adoption Ban, 51 U. MiAmi L. ReV. 151, 154-55 (1996) citing Fla. S. Jour., 1977 Org. Sess. at 370-71. In 1997, Florida passed legislation that refuses recognition of marriages between persons of the same sex and "relationships between persons of the same sex which are treated as marriages . . . for any purpose," and orders all agencies, and political subdivisions to give no effect to any "public act, record, or judicial proceeding" of any other political entity "respecting either a marriage or a relationship not recognized . . or a claim arising from such a marriage or relationship." FLA. STAT. § 741.212 (2006). The statute has been sustained in a challenge on federal constitutional grounds. Wilson v. Ake, $354 \mathrm{~F}$. Supp. 2d 1298 (M.D. Fla. 2005) (finding that statute did not violate the U.S. Constitution under the Full Faith \& Credit, Due Process, Equal Protection, Privileges or Immunities, or Commerce Clauses).

27 See, generally, Terl, supra note 21, at 809-21.

28 Terl, supra note 21 , at $818,822$.

29 Seebol v. Farie, 16 Fla. L. Weekly C52 (16th Cir. Ct. Mar. 15, 1991), reprinted in Florida Dep't of Health \& Rehab. Servs. v. Cox, 627 So. 2d 1210, 1221-29 (Fla. 2d Dist. Ct. App. 1993).

30 Id.

31 Id. Since the Seebol decision, the 11th Circuit Court of Appeals declared the Florida statute constitutional in Lofton v. Secretary of Department of Children and Family Services. As an interesting aside, the 11th Circuit seemingly glossed over the Seebol outcome even while citing it, stating, "To date, no attempt to overturn the provision has succeeded." 358 F.3d 804, 807 (11th Cir. 2004). Because the Seebol Court relied on both the Florida Constitution and U.S. Constitution in reaching its privacy, due process, and equal protections arguments, there may remain a question as to whether the Lofton Court reversed the Seebol decision. 
a special needs child. ${ }^{32}$ On summary judgment, the trial court ruled $\S$ 63.142(3) void for vagueness and unconstitutional under Florida's constitutional right to privacy and equal protection. ${ }^{33}$ This success was short-lived, however, as the Department of Health and Rehabilitative Services (HRS) appealed the case. In an exhaustive opinion, the Second District Court of Appeal of Florida reversed the decision on procedural grounds as well as on the vagueness, privacy, due process and equal protection issues, and remanded the case. ${ }^{34}$ The ACLU then appealed to the Florida Supreme Court, which granted review in Cox v. Florida Department of Health and Rehabilitative Services. ${ }^{35}$ In a per curiam opinion, the Court affirmed the district court's decision as to the procedural, vagueness, privacy and due process issues, but ruled that "the record is insufficient to determine that this statute can be sustained against an attack as to its constitutional validity on the rational-basis standard for equal protection. ${ }^{, 36}$ It directed a remand on the equal protection issues only. ${ }^{37}$ The case ended quietly, however, when the petitioners took a voluntary dismissal. ${ }^{38}$

In 1995, the ACLU moved forward yet a third case that had been filed in 1992, but was stayed pending the outcome in the Cox case. ${ }^{39}$ June Amer, a corrections officer, was not permitted to even apply to adopt a child by Florida's Department of Health and Rehabilitative Services because she was a lesbian. ${ }^{40}$ The ACLU worked to cure the failings of the Cox case by building a record that elicited expert testimony from psychologists, pointed to the inconsistencies in banning homosexuals from adoption but not from foster parenting and noting the fact that Ms. Amer was already parenting a 6 year-old son, all in an effort to undermine the "rational" basis of the law. Their arguments were not convincing, however, and the trial court sustained the statute. ${ }^{42}$

\footnotetext{
32 Florida Dep't of Health \& Rehab. Servs. v. Cox, 627 So. 2d 1210, 1212-13 (Fla. 2d Dist. Ct. App. 1993).

33 Id.

34 Id.

35 Cox v. Florida Dep't of Health \& Rehab. Servs., 637 So. 2 d 234 (Fla. 1994) (granting review).

36 Cox v. Florida Dep't of Health \& Rehab. Servs., 656 So. 2d 902, 903 (Fla. 1995). See Lee, supra note 26, (providing insights to legislative history of statute and background to case).

37 Cox, 656 So. $2 \mathrm{~d}$ at 903.

38 Terl, supra note 21 , at 824 .

39 Id.

40 Donna Leinwand, Gay Adoption Ban Upheld: Lesbian Loses Her Case Against 1977 State Law, Miami HeRALD, July 29, 1997, at B1.

41 Press Release, American Civil Liberties Union, Trial Opens in Challenge to Florida Adoption Law Barring Lesbian Moms and Gay Dads (May 5, 1997), available at http://legalminds.lp.findlaw.com/list/queerlaw-edit/msg00656.html. Policies of Florida's Department of Health and Rehabilitative Services to bar unmarried couples and homosexuals from serving as foster parents were struck down in 1994. Matthews v. Weinberg, 645 So. 2d 487, 490 (Fla. 2d Dist. Ct. App. 1994) (finding that the agency had exceeded its delegated rule-making authority).

42 Amer v. Johnson, 4 Fla. L. Weekly Supp. 854b (Fla. 17th Cir. Ct. 1997).
} 
Another challenge to Florida's ban on gay adoptions was filed in federal court by the ACLU, and it, too, failed to overturn the statute. ${ }^{43}$ In Lofton v. Secretary of the Department of Children and Family Services, the 11th Circuit Court of Appeals considered the appeal of six plaintiffs who challenged Florida's ban on gay adoptions on federal constitutional issues, and had lost on summary judgment. ${ }^{44}$ The three foster parents, one legal guardian, and two of their minor children (one of the foster children and the child under guardianship care) made three claims: that the statute violated their due process rights to familial privacy, intimate association and family integrity; that their fundamental rights to private sexual intimacy as espoused by the U.S. Supreme Court's decision in Lawrence v. Texas were violated; ${ }^{45}$ and that the statute's differing treatment of homosexuals under law was a transgression of the 14th Amendment's Equal Protection Clause. ${ }^{46}$ The Court denied each of the claims, holding that foster parents and legal guardians do not enjoy the constitutional rights afforded to legal parents, and thus, could not claim the rights of family privacy and integrity, and intimate association. ${ }^{47}$ Cabining the U.S. Supreme Court's decision in Lawrence, the Lofton Court also posited that the Supreme Court had not elevated private adult sexual conduct to a fundamental right, but had merely afforded it more protection under the Constitution. ${ }^{48}$ Finally, the 11 th Circuit panel applied a rational basis test to evaluate the plaintiffs' equal protection claims, finding that Florida's argument that the "best interests of the child" would be served by placing children in homes with heterosexual parents was not irrational. ${ }^{49}$ A motion for an en banc hearing, which was denied by a divided court (7-5), elicited even more text on the substantive

43 Lofton v. Sec'y Dep't of Children \& Family Servs., 358 F.3d 804 (11th Cir. 2004).

44 Lofton v. Kearney, 157 F. Supp.2d 1372 (S.D. Fla. 2001) (granting summary judgment to the State of Florida), aff'd subnom. Lofton v. Sec'y Dep't of Children \& Family Servs., 358 F.3d 804 (11th Cir. 2004). The original suit also included several other plaintiffs who were dismissed earlier for lack of standing. Lofton v. Butterworth, 93 F. Supp.2d 1343, 1348 (S.D. Fla. 2000)

45 Lawrence v. Texas, 539 U.S. 558 (2003).

46 Lofton, 358 F.3d at 809. For analyses and potential applications of the Lofton decision, see, Elizabeth L. Maurer, Errors that Won't Happen Twice: A Constitutional Glance at a Proposed Texas Statute That Will Ban Homosexuals From Foster Parent Eligibility, 5 APPALACHIAN J. L. 171, 181-84 (2006); Christopher D. Jozwiak, Lofton v. Secretary of the Department of Children and Family Services: Florida's Gay Adoption Ban Under Irrational Equal Protection Analysis, 23 LAW \& INEQ. 407 (2005); and Timothy P. Wasyluka, Homosexuals' Rights to Adopt After Lofton v. Secretary of Department of Children and Family Services, 27 AM. J. TRIAL AdVOC. 635 (2004).

47 Lofton, 358 F.3d at 809.

48 Lofton, 358 F.3d at 815-16 (citing Justice Scalia's dissenting opinion and observation that the majority had not declared a "fundamental right," and further noting that the majority had not located the right "directly in the Constitution, but instead treated it as the by-product of several different constitutional principles and liberty interests").

49 Id. at $821-26$. 
issues of the case than did the decision itself. ${ }^{50}$ A subsequent petition by the plaintiffs for certiorari to the U.S. Supreme Court was denied."

Litigation over Florida's adoption ban ceased after the Lofton decision as advocates for gay families struggled to find other legal vehicles with which to challenge the law. In late 2008, two cases-one in Monroe County and the other in Miami-Dade County-challenged the adoption ban successfully. ${ }^{52}$ While the State did not defend the constitutionality of the adoption ban, nor did it appeal that court's order granting the petition to adopt in the Monroe County case, the State did make an appearance to defend the adoption ban in the Miami-Dade proceeding. ${ }^{53}$

Grounded on distinctive legal theories, the two cases are factually similar-prospective fathers sought the adoption of children whom the State had placed in their care as foster parents and the children had lived with the prospective parent for four or more years. ${ }^{54}$ The Monroe County petitioner grounded his case on two theories accepted by the court: a) the adoption ban is a "special law," and as such, violates the Florida Constitution's prohibition on special laws "pertaining to . . . adoption of persons",; and $b$ ) the adoption ban is a bill of attainder, prohibited by both the Florida Constitution and the U.S. Constitution. ${ }^{56}$ The court sua sponte also found that the adoption ban violates the Florida Constitution's separation of powers doctrine grounded in Article II, Section 3, because the legislature had effectively "displaced the inherent authority and concurrent jurisdiction of the adoption court" to determine the best interests of the child.

The Miami-Dade case, argued by the American Civil Liberties Union, rested on substantially different grounds. This court held that state and federal law established a child's right to a permanent home. ${ }^{58}$ The state's adoption ban violated the children's right to permanency as well as their liberty interests. ${ }^{59}$ Furthermore, the court found that the statute violated Florida's constitutional guarantee of equal protection by discriminating against ho-

\footnotetext{
50 Lofton v. Sec'y Dep't of Children \& Family Servs, 377 F.3d 1275 (11th Cir. 2004) (denying petition for rehearing en banc).

51 Lofton v. Sec'y, Dep't of Children \& Families, 543 U.S. 1081 (2005) (denying certiorari).

52 In the Matter of the Adoption of John Doe, 2008 WL 5070056 (16th Cir. Ct. Aug. 29, 2008) (hereinafter "Monroe County case"); In the Matter of the Adoption of John Doe and James Doe, 2008 WL 5006172 (11th Cir. Ct. Nov. 25, 2008) (hereinafter "Miami-Dade County case").

53 At the time of publication, the State had not indicated whether it intends to appeal the ruling.

54 In the Monroe County case, the petitioner and his partner had previously been named permanent guardians of the child by the court.

55 Art, III, Sec. 11(a)(16) Fla. Const.; Monroe County Case, 2008 WL 5070056.

56 Monroe County Case, 2008 WL 5070056 at 22-27.

57 Id., at 27-33.

58 Miami-Dade County Case, 2008 WL 5006172, 21-25 (relying on Florida Supreme Court decisions, Florida statutes, and the federal Adoption and Safe Families Act of 1997 (42 U.S.C. § 671)).

59 Id.
} 
mosexuals and against children who are foster-parented by homosexuals. ${ }^{60}$ Employing a rational basis standard of review, the court rejected each of the three arguments posited by the State as justifications for the adoption ban: that the ban promotes the well-being of children, ${ }^{61}$ minimizes the social stigmatization the children may experience, ${ }^{62}$ and promotes public morality. $^{63}$

These two cases are surely not the final words on Florida's adoption ban. Lawyers will continue to consider alternate strategies for creating gay and lesbian families that work around Florida's laws, and attempt to effect policy change through the legislative process by whittling away at the language of the adoption statute. ${ }^{64}$ But as gay rights organizations achieve legal successes in other states, strategies for importing those successes into Florida and Florida law, either directly or indirectly, can serve as vehicles for the recognition of lesbian and gay family relationships that Florida law persistently refuses to acknowledge.

\section{CREATING LESBIGAY FAMILIES IN FLORIDA}

The question of "how" to have a legally recognized child is generally not an issue for married heterosexual couples. In Florida, the child of a married couple is presumptively assumed to have a mother - the birth mother-and a father, her husband, and heterosexual families gain legal recognition at their child's birth. ${ }^{66}$ But for gay men and lesbian couples whose relationships remain legally non-existent in Florida and in most

$60 \quad I d$. , at $25-29$.

61 Id. at 28

$62 \mathrm{Id}$.

63 Id. at 29.

64 A bill that would permit limited adoptions by individuals who are gay or lesbian has been introduced for consideration during the 2008 Florida Legislative Session. The bill would permit adoptions by gays or lesbians when the child's parents are deceased, the prospective adoptive parent is the child's legal guardian, and the child already resides with the prospective parent. Relating to Adoption, S.B. 0200 (similar H.B. 0045), 2008 Fla. Leg. Sess. (Fla. 2007). State chapters of national gay rights organizations and local organizations recognize the importance of educating and reshaping public opinion in Florida, and have mounted campaigns that focus on education and social change. For a discussion of public opinion on Florida's adoption ban, see Scott D. Ryan, Laura Bedard \& Marc Gertz, Florida's Gay Adoption Ban: What Do Floridians Think?, 15 U. FLA. J.L. \& PUB. POL'Y 261 (2004).

65 Consider the implications for Florida of a recent decision by the U.S. Court of Appeals for the Tenth Circuit, striking down Oklahoma's Adoption Invalidation Law, and requiring that state to recognize adoption decrees issued by courts outside of Oklahoma even when the adoptive parents are a samesex couple. Finstuen v. Crutcher, 496 F.3d 1139 (10th Cir. 2007).

66 '"Parent' means a woman who gives birth to a child and a man whose consent to the adoption of a child would be required under s. 63.062(1). If a child has been legally adopted, the term 'parent' means the adoptive mother or father of the child." FLA. STAT. § 39.01(48) (2006). Florida also defines "family" as "a collective body of persons, consisting of a child and a parent, legal custodian, or adult relative, in which: (a) The persons reside in the same house or living unit; or (b) The parent, legal custodian, or adult relative has a legal responsibility by blood, marriage, or court order to support or care for the child.” FLA. STAT. § 39.01(30) (2006). 
states, family creation is the model of family planning and choice. ${ }^{67}$ The first hurdle for them is generally "how" to have a child. While there are gay men and lesbians who are raising children from previous heterosexual relationships, for most lesbigay families, family creation in Florida is a twostep process: they must first decide on how to have a child and determine which adult will be the first parent, and then attempt to gain legal recognition of the other partner as a second parent. ${ }^{68}$ In the balance of this Comment, I focus on the first hurdle for childless gay and lesbian singles and couples in Florida, how to have a child. ${ }^{69}$ Depending on the couple's situation and the law, three avenues of family-building may be available to prospective gay and lesbian parents: single-parent adoptions, artificial insemination, and surrogacy.

\section{A. Single-Parent Adoption}

Single-parent adoptions by gay men and lesbians do take place in Florida despite the statutory ban on adoptions by a "homosexual." "70 These adoptions are likely uncontestable in the legal arena for two reasons. First, the state legislature failed to define "homosexual" in crafting the adoption statute and courts have relied, instead, on a definition of "homosexual" that is both narrow and vague. Second, once any adoption is approved, Flor-

67 Some states have legally recognized the relationships of same-sex couples, and have done so through a variety of arrangements. As of February 2008, Massachusetts was the only state to fully recognize same-sex marriage. California's Supreme Court heard consolidated oral arguments on March 4, 2008, in the four cases that grew out of San Francisco's marriage event in 2003, and the Court is expected to render a decision on that state's same-sex marriages within 90 days. In re: Marriage Cases, 149 P.3d 737 (Cal. 2006) (granting review). Vermont, Connecticut, New Jersey and New Hampshire recognize civil unions, while California and Oregon afford domestic partnerships to same-sex couples. Maine, Washington and the District of Columbia have limited relationship recognition laws, and Hawaii allows for reciprocal beneficiaries. The National Gay and Lesbian Task Force, Relationship Recognition for Same-Sex Couples in the U.S. (February 22, 2008), http://www.thetaskforce.org/reports_and_ research.

Other countries have also accorded legal recognition to same-sex relationships. Marriage, with all of the rights accorded to a marital couple, is now permitted in five nations: Netherlands (2001), Belgium (2003), Spain (2005), Canada (2005) and South Africa (2006). Civil unions have a longer history that date back to Denmark's recognition in 1989, and in many cases, these national laws provide registered couples with full family rights, including the right to adopt and co-parent. Norway, Sweden, Iceland and Finland extend many of the marital benefits to a same-sex couple through civil unions and domestic partnership recognition.

68 Courtney G. Joslin, The Legal Parentage of Children Born to Same-Sex Couples: Developments in the Law, 39 FAM. L. Q. 683 (discussing early gay parenting litigation arising from custody disputes between former different-sex spouses).

69 Subsequent research will examine the second phase of family creation in Florida, specifically, gaining legal recognition for the second parent.

70 Note that Florida law permits an unmarried or single adult to adopt. FLA. STAT. § 63.042(2)(b) (2006). 
ida's statute of repose limits who may challenge an adoption, and establishes a time limit to those contests. ${ }^{71}$

\section{1. "Homosexual" Defined}

The adoption ban statute fails to define "homosexual." While a judicially-constructed definition has been adopted and is recognized by most Florida courts, it is conduct-based and casts a narrow category of sexual acts, it does not encompass sexual orientation, and it leaves an essential component of the adopted definition unspecified. As a result, gay men and lesbians can and do, in good faith, deny being "homosexual" under Florida law. $^{72}$

The State of Florida identifies persons ineligible to adopt under the ban by asking them to self-identify as homosexuals or bisexuals on the Adoptive Home Application required by the Department of Children and Families for all adoptions. ${ }^{73}$ On the application, Item $\mathrm{II}(\mathrm{G})$ reads as follows: "Section 63.042(3), F.S., states that "no person eligible to adopt under this statute may adopt if that person is a homosexual." "T4 statement are two items, with check-boxes for "Yes" and "No" answers by the potential adoptive parents (Husband [Man]/Wife [Woman]). The first seeks a response to the statement, "I am a homosexual." The second item seeks a response to the statement, "I am bisexual.", The application does not provide definitions of homosexual or bisexual. In each of the cases that has been litigated in Florida courts, the petitioners either refused to mark an answer but was known to be homosexual, ${ }^{76}$ proffered to the agency in ad-

71 While there is an on-going debate in the legal academy regarding adoptions by gay, lesbian, and transgendered persons, this Comment focuses solely on the legal issues involved in lesbigay parenting. See, e.g., Carlos A. Ball, The Immorality of Statutory Restrictions on Adoptions by Lesbians and Gay Men, 38 LoY. U. CHI. L.J. 379 (2007) (examining the immorality of Florida and Oklahoma's antigay adoption statutes); Lynne Marie Kohm, Moral Realism and the Adoption of Children by Homosexuals, 38 NEw ENG. L. REV. 643 (2004) (concluding that it is in the best interests of every child to have a mother and father who are married to each other).

72 Not discussed here, but worthy of recognition, are the personal dilemmas that one confronts in openly denying their sexual orientation, regardless of an established legal definition. The politics and personal costs of the closet have been deliberated at length by the gay community. See, e.g., BRUCE Bawer, A Place at the Table 236-254 (Ann Patty ed., Poseidon Press 1993); Michael Warner, The Trouble With NoRmal: SeX, Politics, AND the Ethics of QueER LifE (Harv. Univ. Press 1999).

73 Florida Dep't of Children \& Families, Adoptive Home Application, CF-FSP 5071 (03/2007).

74 Id. at 4

75 The inclusion of the "bisexual" question supports an interpretation of the ban as a conductbased, and not as an identity-based determination. Note that no challenge has been made to the adoption ban by a bisexual even though it is believed that the incidence of bisexuality is greater than homosexuality. See Kenji Yoshino, The Epistemic Contract of Bisexual Erasure, 52 STAN. L. R. 353 (2000) (arguing that despite a greater incidence of bisexuality both homosexuals and heterosexuals benefit from distinct orientation classifications that exclude bisexuals and bisexuals have contributed to their own erasure).

76 That Steven Lofton, one of the plaintiffs in the only federal case to challenge Florida's adoption ban, had refused to answer the homosexuality question on his adoption application became an issue of contention for the State in its Motion for Final Summary Judgment. The State attempted to argue that 
vance that they were "homosexual,"77 or marked the "Yes" box on the application. $^{78}$

No case has been challenged before the Florida courts where an applicant denied being a "homosexual" or "bisexual," and the Department of Children and Families disqualified the applicant on its own finding that the applicant is, in fact, homosexual or bisexual. A challenge in such a scenario would force the state to further clarify its definition of "homosexual," and require that the state introduce evidence and testimony that goes directly to the applicant's conduct and its currency, evidence that is not so easily attained. More importantly, such a challenge would point out the serious flaws in Florida's ban on adoptions by homosexuals.

"Who" is a homosexual was one of several issues at the heart of the only adoption ban case to be decided by Florida's appellate courts. ${ }^{79}$ In Florida Department of Health and Rehabilitative Services v. Cox, Florida's Second District Court of Appeal reversed the trial court's finding that the adoption-ban provision was unconstitutionally void for vagueness. ${ }^{80}$ Decided in the wake of Bowers v. Hardwick, the United States Supreme Court decision that upheld a state's right to criminalize sodomy, ${ }^{81}$ the Cox court grounded its definition of homosexuality in conduct. ${ }^{82}$ Because the statute fails to define "homosexual," the court agreed to adopt the state's argument that Florida should rely on a definition used by New Hampshire, the only other state with a statutory ban on homosexual adoptions at that time. ${ }^{83}$

In New Hampshire, at the urging of its Supreme Court, the state legislature developed a definition of homosexual to be used specifically in the

Lofton, who had been a foster parent for over ten years, was denied permission to adopt because he failed to submit a complete application. The court rejected that argument, calling it "disingenuous in light of the explicit language of their Answer and the evidence in the Record." Lofton v. Kearney, 157 F. Supp. 2d 1372, 1375 n.3 (S.D. Fla. 2001). The 11th Circuit's opinion notes further that Lofton had also refused to disclose "his cohabiting partner" as a member of his household on the adoption application. Lofton v. Sec'y Dep't of Children \& Family Servs., 358 F.3d 804, 808(11th Cir. 2004).

77 See, e.g., Lofton, 358 F.3d at 808 (discussing Plaintiff Houghton's disqualification due to homosexuality as determined during preliminary home study evaluation).

78 See, e.g., Lofton, 358 F.3d at 808 (discussing Plaintiffs Smith and Skahen having acknowledged that they were gay men on the adoption application).

79 The definition of "homosexual" was first considered in Florida Dep't of Health and Rehab. Servs. v. Cox, 627 So. 2d 1210 (Fla. 2d Dist. Ct. App. 1993). Upon review, the definition was affirmed by the Florida Supreme Court. Cox v. Florida Dep't of Health and Rehab. Servs., 656 So. 2d 902 (Fla. 1995).

80 The trial court had asked the parties to brief the issue and made this finding despite the fact that the petitioners acknowledged they were "homosexual" and had not raised arguments of vagueness or over-breadth in their claim. Florida Dep't of Health and Rehab. Servs. v. Cox, 627 So. 2d at 1214.

81478 U.S. 186 (1986); overruled by Lawrence v. Texas, 539 U.S. 558 (2003) (striking down Texas state sodomy law in favor of a liberty interest in private, consensual sex between adults).

82 Florida Dep't of Health and Rehab. Servs. v. Cox, 627 So. 2d 1210, 1213-15 (Fla. 2d Dist. Ct. App. 1993).

83 New Hampshire adopted its statutory ban in 1987, and repealed it in 1999. N.H. REV. STAT. ANN § 170-B4 (1988). 
context of that state's adoption ban. ${ }^{84}$ A homosexual was "any person who performs or submits to any sexual act involving the sex organs of one person and the mouth or anus of another person of the same gender." ${ }^{, 25}$ The New Hampshire Supreme Court, in reviewing the statute with its amended language, upheld its constitutionality with two caveats: that the definition did not intend to encompass coerced acts, and that "the definition's present tense usage to mean that the acts bringing an individual within the definition's ambit must be or have been committed or submitted to on a current basis reasonably close in time to the filing of an application for licensure or a petition for adoption." 86

In adopting the New Hampshire definition, the Florida court in Cox noted that the state agency in charge of adoptions submitted that it would only bar adoptions "when it knows of current, voluntary homosexual activity by an applicant." ${ }^{, 87}$ The Cox Court thus found the definition of a homosexual to be reasonable, and that it concerned a person's conduct and not their thoughts or orientation. ${ }^{88}$ Finally, the Cox Court also concluded that the Florida legislature was not required to use "precise anatomical language in order for a person of common understanding and intelligence to appreciate that homosexual activity intended by the Florida statute is the same as that described in the New Hampshire statute." ${ }^{89}$ This approach was subsequently affirmed on review by the Florida Supreme Court. ${ }^{90}$ Five years

84 New Hampshire permits judicial review of legislation prior to enactment at the request of the legislature. When the New Hampshire legislature first referred the proposed legislation banning homosexual adoptions, the Court "requested to be excused from giving an opinion" until the legislature provided a definition of "homosexual" and provided a "statement of factual findings about the nexus between homosexuality as the legislature would define it and the unfitness of homosexuals as declared by the bill." Opinion of the Justices, 522 A.2d 989 (N.H. 1987). Of particular relevance was the court's discussion of possible definitions:

While "homosexual" is understood generally to refer to a person who sexually prefers another of his or her own sex, the court does not know how broadly or narrowly the House of Representatives would desire that definition to be applied in administering the statute. For example, should "homosexual" be limited to those currently engaging in physical homosexual practices, should it apply to any person who has ever at any time engaged in such a practice or could it apply to a person who considers himself or herself to be a homosexual but who has never performed a homosexual act? Should homosexual practices include any form of sexual contact, as defined in RSA 632-A:1, IV, or should "sexual penetration," as defined in RSA 632-A:1, V, be required? Should "homosexual" refer to a bisexual person? 522 A.2d at 990 . The Court subsequently rendered a full review of the proposed statute after the legislature included a definition of "homosexual." Opinion of the Justices, 530 A.2d 21, 24 (N.H. 1987).

85 N.H. Rev. Stat. Ann. § 170-B:2 (1991).

86 Opinion of the Justices, 530 A.2d 21, 24 (N.H. 1987). The court further explained, "This interpretation thus excludes from the definition of homosexual those persons who, for example, had one homosexual experience during adolescence, but who now engage in exclusively heterosexual behavior." Id.

87 Florida Dep't of Health and Rehab. Servs. v. Cox, 627 So. 2d 1210, 1214 (Fla. 2d Dist. Ct. App. 1993).

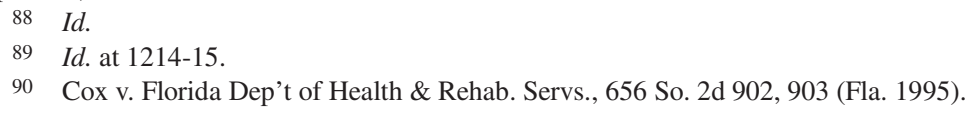


later, in the only federal challenge to Florida's adoption ban, the Lofton plaintiffs failed to challenge the statute as vague or overly broad, a point noted by the District Court in granting summary judgment for the state."

Despite Florida's adoption of New Hampshire's statutory language, the answer to the question of who is a "homosexual" under Florida state law remains a murky one. ${ }^{92}$ One point of contention goes to the nature of the sexual activity adopted from the now-repealed New Hampshire law. ${ }^{93}$ By crafting an anatomically-specific statute, the definition fails to recognize a broad range of sexual activities engaged in by gay men and lesbians that are not included in the New Hampshire criteria. ${ }^{94}$ A gay couple could avoid the classification of "homosexual" by simply not engaging in the specific forbidden acts. ${ }^{95}$ A second shortcoming of the judicially-constructed definition is its failure to define what constitutes "current" homosexual activity. In grappling with this issue in its advisory opinion, the New Hampshire Supreme Court gave a single example of what it would not consider current homosexual conduct, but that court did not attempt to interpret "currency." "96 Is abstinence from engaging in the forbidden acts for a day, a week, a month, or a year sufficient to overcome the "currency" criteria?

Finally, the state faces a certain difficulty in establishing that an applicant has lied on his or her application, or that the applicant has engaged in current homosexual activity without the state crossing the threshold of the applicant's bed chambers at an indiscrete moment. If an applicant truthfully denies the "I am a homosexual" query, the agency may have a difficult time making a determination as to the homosexual conduct of the applicant. Even if neighbors, friends and colleagues interviewed during the adoption process all acknowledge that the applicant has a "homosexual orientation," none are likely to have the knowledge of explicit sexual practices required by the definition. The Second District Court of Appeal recognized that it

91 Lofton v. Kearney, 157 F. Supp. 2d 1372, 1374 n.2 (S.D. Fla. 2001).

92 Beyond the scope of this Comment is the scholarly conversation about identity construction and classificatory authority, especially with respect to race, gender and sexual relationships. By defining homosexuality strictly as conduct, the State may have avoided embroiling itself in the debate over sexual orientation and homosexual behavior. See, e.g., Kenji Yoshino, Covering, 111 YALE L.J. 169 (2002) (challenging the traditional legal identity paradigm through gay practices of conversion, passing and covering); M.C. Mirow, Kennewick Man, Identity, and the Failure of Forensic History, in HISTORY in COURT: Historical EXPertise AND Methods in A Forensic ConTEXt 241, 264 (Alain Wijffels, ed., Studia Forensia Historica No.3, 2001) (recognizing legislative role in constructing legal identities even when they are "inconsistent with identities based on other references"); Mary Coombs, Interrogating Identity, 11 BERKELEY WOMEN's L.J. 222, 230-38 (1996) (reviewing JUDY SCALES-TRENT, NoteS of A White Black Woman: Race, Color, COMmunity, (1995)).

93 See supra note 71.

94 This is especially true in an era of "safe sex" where many couples, gay and straight, specifically avoid the possible exchange of bodily fluids.

95 For example, the use of sex "toys" and manual manipulation between same-sex partners do not constitute homosexual conduct under the Florida statute.

96 See supra note 74 and accompanying text. 
was working with a narrow definition in its decision in Cox, stating, "We recognize that a definition of "homosexual," limited to applicants who are known to engage in current, voluntary homosexual activity, draws a distinction between homosexual orientation and homosexual activity." however, signal the legislature that the elected body had the power to expand the definition "without any mandate from this court."

While a strict definition of "homosexual" rooted in current conduct may be recognized and upheld in a judicial arena, what happens "in the field" at the hands of social workers assigned to conduct home surveys may result in the application of a definition of "homosexual" that cuts more closely to homosexual orientation than homosexual conduct. Florida law requires that a petition to adopt be accompanied by the results of a favorable preliminary home study. ${ }^{99}$ Conducted by a licensed child-placement agency, a registered child-care agency, a licensed professional or state agency, the home study is based on interviews with the prospective parents, criminal background and abuse registry checks, verification of the adoptive parents' financial security, "an assessment of the physical environment of the home," and documentation of counseling on the adoption process, adoptive parenting, and support services. ${ }^{100}$ The "Family Safety and Preservation Program" of the Department of Children and Family Services requires that the home study consider a litany of factors including five written recommendations, and it requires prospective parents to sign an affidavit of good moral character, attesting to their own good moral character. ${ }^{101}$

While a prospective gay parent may deny being a current practicing homosexual, the home study can undoubtedly raise questions in the evaluator's mind that could result in an unfavorable home study. A single man who is too effeminate or a woman who is too masculine may be perceived by the social worker, correctly or even incorrectly, as homosexual. Two unrelated adult women or men cohabitating may be treated by the reviewing agency as "homosexual," regardless of the applicant's negative response on the application. Or the prospective parent may be asked outright about

97 Florida Dep't of Health and Rehab. Servs. v. Cox, 627 So. 2d 1210, 1215 (Fla. 2d Dist. Ct. App. 1993). The court also limited its decision to the facts at hand: "We do not need to determine what steps HRS would be entitled to take in the best interests of children if an applicant declined to answer these questions." 627 So. $2 \mathrm{~d}$ at 1217.

98 Id. at 1215 (stating that the "legislature is constitutionally permitted to reach its own conclusions on the validity of the distinction between homosexual orientation and activity without any mandate from this court.")

99 FLA. STAT. § 63.112(2)(B) (2006).

100 FLA. STAT. § 63.092(3) (2006).

101 Fla. Admin. CODE ANN. R. 65c-16.005(3)(m) (2003). The affidavit serves as the affiant's acknowledgement or denial that the affiant has been found guilty or entered a plea of nolo contendere to a list of criminal charges ranging from murder to child abuse to sexual misconduct. Florida Department of Children and Families, Affidavit of Good Moral Character, Form 1649 (2007), available at http://www.dcf.state.fl.us/DCFForms/Search/DCFFormSearch.aspx. 
living arrangements. For example, consider the facts in a foster care case where, during the home study and survey of the placement home, the prospective parent was asked if her female roommate "slept in the same bedroom." If 102 the answer is "yes," the social worker will probably assume that they engage in homosexual conduct, even if they do not.

While not rejecting the application on the basis of "homosexual conduct," agency supervisors may also reject applicants using other grounds as a cover for their own perception that the applicant meets the state's definition of homosexual. When this happens, applicants may have little recourse in appealing the state's finding. Because adoption in Florida is a statutory privilege and not a fundamental right, the state enjoys wide discretion in its placement decisions. Add to this discretion the state's reliance on determining what is in the best interests of children, and a "very substantial state interest" is recognized by the courts that may be difficult to rebut by even misidentified heterosexuals. ${ }^{103}$

\section{Statute of Repose}

A prospective gay or lesbian parent, who in good faith denies current homosexual conduct and is subsequently approved for a placement, enjoys the same legal protections following the adoption afforded to other adoptive parents. Florida law provides all adoptive parents with an assurance that the court orders establishing their legal status are final one year after the adoption judgment. State law subjects adoption orders to an independent statute of repose. ${ }^{104}$ For gay and lesbian parents, the statute can serve as an effective legal tool in rebutting future challenges to their adoption orders. The legislative and legal history of the statute of repose suggests that the law establishes a fairly substantial bar against any proceedings to unsettle an adoption order after the one-year period, even if a petitioner alleges fraud on issues other than the requisite consent to adopt. Moreover, the law

102 When she replied that they did, the Health and Rehabilitative Services official asked her if they were homosexuals; the prospective parent's truthful response resulted in an unfavorable home study. The state statute, however, does not forbid gays and lesbians from becoming foster parents. Matthews v. Weinberg, 645 So. 2d 487 (Fla. 2d Dist. Ct. App. 1994) (holding that state agency had no authority to establish policy prohibiting homosexual and unmarried persons from being foster parents). Despite arguments by prospective gay parents that permitting homosexuals to be foster parents while prohibiting them from being adoptive parents constitutes evidence of an irrational relationship between the statute and the state's asserted legitimate interest in protecting children, the federal court found no equal protection violation and found that the foster parent classification was an executive branch consideration, not a legislative one. Lofton v. Sec'y Dep't of Children \& Family Servs., 358 F.3d 804, 823-26 (11th Cir. 2004).

103 Florida Dep't of Health and Rehab. Servs. v. Cox, 627 So. 2d 1210, 1216, 1220 (Fla. 2d Dist. Ct. App. 1993).

104 FLA. STAT. § 95.11 (2006) (establishing general statute of limitations); FLA. STAT. § 63.182(1) (2006) (establishing statute of repose with respect to adoptions). 
imposes strict limits on "who" may challenge adoption orders regardless of when that challenge is filed.

Historically, Florida courts have reversed adoption orders that were gained through fraud on the biological mother. ${ }^{105}$ The statute of repose, adopted in a modernization of Florida's adoption laws in 1973, cured procedural defects and irregularities in adoption orders, and provided that any "direct or collateral attack" on the validity of the judgment was barred, even as to the issue of consent to the termination of parental rights, if the matter could have been cured during the adoption proceedings. ${ }^{106}$ Courts, however, read "irregularity" narrowly and continued to permit claims based on fraud to be raised beyond the time limits set by the statute of repose. ${ }^{107}$ In 2000, the legislature revised the statute to specifically address claims based on fraud. ${ }^{108}$ Retaining the one-year limitation for all procedural challenges, it established a new two-year limitation for fraud claims. ${ }^{109}$ In effect, the statutory revision limited judicial discretion by prohibiting courts from considering stale claims of fraud as grounds for reversing adoption orders.

The most recent amendment to the statute eliminated any mention of claims based on fraud. Included in the Florida Adoption Act of 2003, the current statute of repose bars "an action or proceeding of any kind to vacate, set aside or otherwise nullify" an adoption order filed more than one year after entry of the judgment "on any ground" (emphasis added). ${ }^{110}$ However, this does not foreclose claims by persons whose consent to an adoption are required by the adoption laws. Under Florida Statute s. 63.082(4)(b) (2006), a consent "may be withdrawn only if the court finds that it was obtained by fraud or duress." Other claims of fraud, however, are barred one year after the execution of the adoption order. ${ }^{11}$

What may be even more important for gay and lesbian families is that the recent amendment to the statute of repose added a section that limits who may challenge adoption orders, regardless as to the timing of those

105 See, e.g., In re adoption of Shea, 86 So. 2d 164 (Fla. 1956) (affirming existence of fraud sufficient to overturn adoption order); Petition of Gaban, 30 So. 2d 176 (Fla. 1947) (finding for natural mother who signed away rights following childbirth and under effects of anesthesia); Lambert v. Taylor, 8 So. 2d 393 (Fla. 1942) (finding for natural mother duped into signing away her rights).

106 FLA. STAT. § 63.182 (1974); 1973 Fla. Laws c. 73-159, § 18.

107 Preston v. Tolone, 661 So. 2d 967 (Fla. 5th Dist. Ct. App. 1995) (remanding for evidentiary hearing on fraud claims, which, if substantiated, may result in setting aside of adoption); Peregood v. Cosmides, 663 So. 2d 665 (Fla. 5th Dist. Ct. App. 1995) (citing M.L.B. v. Dept of Health \& Rehabilitative Svcs., 559 So. 2d 87 (Fla. 3d Dist. Ct. App. 1990) and finding motion to annul adoption due to fraud by state agency not barred by statute of repose); but see Calderon v. Torres, 445 So. 2d 1040 (Fla. 3d Dist. Ct. App. 1984) (applying statute of repose to claim of fraud in adoption seven years earlier).

1082000 Fla. Laws c. 2000-188, § 6.

109 FLA. STAT. § 63.182(2) (2002); 2000 Fla. Laws c. 2000-188, § 6.

1102003 FLA. LAWS c. 2003-58.

111 Id. 
proceedings. ${ }^{112}$ A party seeking to challenge a judgment of adoption, other than those entitled to notice in accordance with the general adoption statute ${ }^{113}$ must establish an interest that is "direct, financial, and immediate, and the person must show that he or she will gain or lose by the direct legal operation and effect of the judgment." 114 An interest that is "indirect, inconsequential or contingent" is not sufficient to establish standing to challenge an adoption order. ${ }^{115}$ Thus, challenges by interest groups opposed to gay adoptions and disapproving family members who seek to unsettle the adoption should be barred simply because they have no standing.

Problematic, however, is the possibility that a court would permit an adopted child to challenge her own adoption by and through a guardian $\mathrm{ad}$ litem or "next friend." Although not arising in the context of gay parents, such a case was considered in Peregood v. Cosmides, where a two-year old child filed a petition to vacate and rescind a final judgment of adoption. ${ }^{116}$ In this case, the natural parents had entered into a creative legal agreement whereby the father would be relieved of his child support payments in return for foregoing future visitation rights with the child. ${ }^{117}$ To effect the agreement, the natural parents each consented to terminating their parental rights over their son and making him available for adoption. The mother then adopted her son as sole parent. ${ }^{118}$ Shortly after the adoption was finalized, the deal began to unravel when it became clear that the mother could not financially sustain herself and the child. As a result, suit was brought in

112 FLA. STAT. § 63.182(2)(a) (2006).

113 Florida law requires notice to grandparents in some cases where the child has lived with the grandparent for at least six months within the two-year period preceding a termination of adoption. FLA. STAT. $\$ 63.0425$ (2006). Consent to adopt, and thus, notice is also required under FLA. STAT. $\S$ 63.062(1) (2006), by:

(a) The mother of the minor.

(b) The father of the minor, if:

1. The minor was conceived or born while the father was married to the mother;

2. The minor is his child by adoption;

3. The minor has been established by court proceeding to be his child;

4. He has filed an affidavit of paternity pursuant to s. 382.013(2)(c); or

5. In the case of an unmarried biological father, he has acknowledged in writing, signed in the presence of a competent witness, that he is the father of the minor, and has filed such acknowledgement

(c) The minor, if 12 years of age or older, unless the court in the best interest of the minor dispenses with the minor's consent.

(d) Any person lawfully entitled to custody of the minor if required by the court.

(e) The court having jurisdiction to determine custody of the minor, if the person having physical custody of the minor does not have authority to consent to the adoption.

114 FLA. STAT. § 63.182(2)(a) (2006).

115 Id.

116 Peregood v. Cosmides, 663 So. 2d 665 (Fla. 5th Dist. Ct. App. 1995); see also In re T.W., 551 So. 2d 1186, 1188 (appointing guardian ad litem for fetus in parental consent abortion case).

117 Id. at 667 .

118 Id. 
the child's name against both of his parents, "through his best friend, his maternal grandmother," challenging the final judgment of adoption. ${ }^{119}$ While the court recognized that the child had standing to challenge his adoption, it limited its opinion to the "unusual facts surrounding this case, and that this opinion is to be narrowly construed."

Florida's ban on homosexual adoptions can be legitimately avoided by prospective gay and lesbian parents if they understand how the state has defined "homosexual," and that the definition is limited to specific acts engaged in "currently" rather than an orientation or preference. But because the statement that the state asks prospective parents to answer on their adoption applications is framed so bluntly and fails to provide any definition of "homosexual" or "bisexual," prospective parents must be counseled as to the definition, and advised that no court has interpreted what would be considered "current" homosexual activity. Further legal challenges to the deceptive wording of the adoption application or a suit where the state has denied an adoption application based on the adoption ban to a prospective parent who denied being a homosexual may be the only avenues left in a future round of legal challenges.

\section{B. Artificial Insemination}

Lesbian couples and single women generally enjoy both a biological and legal advantage over gay men when it comes to family creation in that they can start their families by artificial insemination. One woman agrees to serve as the biological and natural mother of the child, and is inseminated with donor sperm. ${ }^{121}$ With much planning and a little luck, she will become pregnant and bear a child who is her natural child. Florida law provides that "the donor of any egg, sperm, or preembryo, other than the commissioning couple or a father who has executed a preplanned adoption agreement under s. 63.212, shall relinquish all maternal or paternal rights and obligations with respect to the donation or the resulting children." 122 As a result, a child conceived by artificial insemination and born to an unmarried woman will only have its birth mother named on the Florida birth certificate. $^{123}$ This is particularly important to the lesbian couple who may later

119 Id.

120 Id. at 669.

121 The distinction between a biological and natural mother is an important one in reproductive technology cases, and is at the heart of surrogacy disputes. The biological parent is one who is genetically related to the child as a result of conception using that person's egg or sperm. The natural or birth mother is the woman who physically carries and births the child. In cases of gestational surrogacy, the birth mother may not be the biological parent. See discussion infra pp. 38-39.

122 FLA. STAT. $\$ 742.14$ (2006).

123 "If the mother is not married at the time of birth, the name of the father may not be entered on the birth certificate without the execution of an affidavit signed by both the mother and the person to be named as the father." FLA. STAT. § 382.013(2)(c) (2006). 
seek to add a second name to the birth certificate of their Florida-born child. ${ }^{124}$

The issue of sperm donation and paternity claims has been addressed by Florida's appellate courts. In Lamaritata v. Lucas, a man brought a paternity suit to establish himself as the father of twins born as a result of artificial insemination. ${ }^{125}$ On appeal, the man claimed that he was not a sperm donor under Florida law, ${ }^{126}$ and that he and the birth mother were a "commissioning couple," and therefore, he was exempted from the statute. ${ }^{127}$ The court rejected his arguments. While recognizing that "sperm donor" is not defined in the statute, the court noted that the contract called him a "donor" and "that sperm is the only donation required of him." 128 The court also rejected his suggestion that the birth mother and he constituted a commissioning couple, defined by the statute as "the intended mother and father of a child who will be conceived by means of assisted technology using the eggs or sperm of at least one of the intended parents." ${ }^{, 29}$ As the couple had only agreed to the donation of sperm for artificial insemination and had not agreed to jointly raise the children, they did not constitute a commissioning couple. $^{130}$ The court ruled that, "[a] person who provides sperm for a woman to conceive a child by artificial insemination is not a parent. . . If the sperm donor has no parental rights, the sperm donor is a nonparent, a statutory stranger to the children.",131

In Budnick v. Silverman, an unmarried woman entered into a "Preconception Agreement" with a man in which they agreed to have intercourse for the purpose of conceiving a child. ${ }^{132}$ The terms of the arrangement stated that the woman would be sole custodian of the child and pay for all expenses; she would not identify him as the biological father nor initiate a paternity action against him. ${ }^{133}$ She further agreed that if she violated the agreement, he could seek "full and complete and permanent custody and guardianship of the child." ${ }^{, 134}$ A child was conceived as a result of the rela-

124 The potential for legal co-parenting in Florida will be the focus of subsequent research.

125 Lamaritata v. Lucas, 823 So. $2 d 316$ (Fla. 2d Dist. Ct. App. 2002). For a discussion of the facts and background to the case, see, L.A.L. v. D.A.L., 714 So. 2d 595 (Fla. 2d Dist. Ct. App. 1998).

126 FLA. STAT. § 742.14 (2006).

127 Lamaritata, 823 So.2d at 318-19. A “commissioning couple" is language specific to Florida's gestational surrogacy laws. See discussion infra at pp. 38-40.

128 Lamaritata, 823 So.2d at 318.

129 FlA. STAT. § 742.13(2) (2006).

130 . Lamaritata, 823 So.2d at 316.

131 Id.

132 Budnick v. Silverman, 805 So. 2d 1112, 1113 (Fla. 4th Dist. Ct. App. 2002).

133 Id. Under Florida law, any woman who has a child "may bring proceedings . . . to determine the paternity of a child when paternity has not been established by law or otherwise." FLA. STAT. § 742.011 (2006). Once identified, the father can be held responsible for child support.

134 Budnick, 805 So. $2 d$ at 1113. 
tionship. ${ }^{135}$ When the child was ten years old, the mother filed a Petition for Determination of Paternity naming the "donor" man, claiming the agreement was not cognizable under Florida law, and that it was against public policy. ${ }^{136}$ The trial court granted summary judgment for the man, and the mother appealed. The reviewing court refused to recognize the man as a sperm donor under Florida law, reasoning that the law was created as part of a section on "reproductive technology," and that "[i]mpregnation by the 'usual and customary manner' has been around long enough so that it does not constitute "reproductive technology.", 137 In Budnick and in a subsequent case in Florida, the biological fathers of children conceived through intercourse were ordered to pay retroactive child support as of the child's birth. $^{138}$

In Florida, the legally-optimal scenario for a lesbian who desires to become a natural or biological mother is to seek out the services of a medical provider versed in both the medical and legal issues surrounding artificial insemination. ${ }^{139}$ Whether the sperm used is an anonymous donation from a bank or from a known contributor like a friend, acquaintance, or relative of the couple, ${ }^{140}$ a medical provider can serve as a witness to the fact that the child was conceived through artificial insemination and not through the "usual and customary manner." 141 Working through a sperm bank or medical provider also reduces the possibility that the resulting childbirth would be challenged by the sperm donor in a paternity action because the donor would have completed the requisite forms acknowledg-

135 Id.

136 Id.

137 Id. at 1114.

$138 I d$. Contracts that bargain away a parent's duty to support their child are against public policy and void in Florida because the rights to support and to a parental relationship are rights belonging to the child, not the parent. See, e.g., Bassett v. Saunders, 835 So. 2d 1198, 1201 (Fla. 1st Dist. Ct. App. 2002) (requiring that father pay retroactive child support for child conceived naturally even when he was barred from visitation by mother); Fla. Dep't of Health \& Rehab. Servs. v. Morley, Jr., 570 So. 2d 402 (Fla. 5th Dist. Ct. App. 1990) (striking down divorce agreement between parents where father terminated his parental rights in exchange for relief from child support). Underlying this approach is the traditional notion that "it is rarely in a child's best interests to have fewer adults with duties for the child's care." Brian Bix, Domestic Agreements, 35 HofsTRA L. REV. 1753, 1768 (2007) (noting the countervailing tendency of courts to limit recognition of more than two parents especially with respect to gay parents).

139 Guaranteeing the health of the donor and the sperm is a medical concern in both anonymous and known donations.

140 Before sperm banks were widely accessible (especially to unmarried persons), lesbians regularly asked their gay male friends to serve as sperm donors. With the growing acceptance of homosexuality and the resulting transformation in social attitudes, lesbians are also asking their partner's brothers or male relatives to serve as sperm donors. Biologically, the child is then genetically related to the lesbian partner, typically as her niece or nephew if a brother was the donor. P. Baetens and A. Brewaeys, Lesbian Couples Requesting Donor Insemination: An Update of the Knowledge With Regard to Lesbian Mother Families, 7 HuMAN REPRODUCTION UPDATE 512, 513-14 (2001).

141 Budnick, 805 So. $2 \mathrm{~d}$ at 1113. 
ing his role only as donor and foregoing any claims to paternity. ${ }^{142}$ Some lesbian couples opt for nonprofessional (home-based) artificial insemination using the sperm of friends, acquaintances or relatives; however, a contract that has been reviewed by legal counsel is in the best interest of the couple in order to forestall any success by future paternity claims. ${ }^{143}$

While some lesbian couples may choose to engage in natural copulation with a willing man, the cooperating man is not a "sperm donor" under Florida law, and the lesbian mother runs the risk that the biological father will claim paternity under Florida law. ${ }^{144}$ While Florida's birth registration laws do not permit a birth mother to identify a father on a child's birth certificate if she is unmarried, ${ }^{145}$ the statute does allow unmarried biological fathers the right to notice, and to consent to adoptions of their offspring if they file with the Florida Putative Father Registry. ${ }^{146}$ A paternity claim or putative father registration can complicate prospective adoption proceedings, whether those proceedings are in Florida or another state. The lesbian mother will be required to notice the biological father and gain his consent to any future adoption, requiring that the putative father formally terminate his parental rights to the child. Thus, prospective lesbian parents should only opt for artificial insemination, whether the sperm comes from a known or unknown donor, and should be encouraged to employ the services of a medical provider who can document that the pregnancy was artificially induced.

Because gay and lesbian relationships have not been recognized by the state of Florida, many couples have attempted to rely on the law of contracts to construct family relationships that parallel a heterosexual family. ${ }^{147}$

142 Some lesbian mothers want the biological father to be known to the child and to be a part of the family. Lesbians may use the sperm of the non-birth mother's brother or other male relative in order to form a close genetic bond and legally-cognizable familial relationship between the non-birth parent and the child. See supra note 128. Naming a father may, however, complicate later efforts to secure secondparent adoptions.

143 A contract provides evidentiary support for a donor arrangement in the event of a paternity claim. See, e.g., L.A.L. v. D.A.L., 714 So. 2d 595 (Fla. 2d Dist. Ct. App. 1998); Lamaritata v. Lucas, 823 So. 2d 316 (Fla. 2d Dist. Ct. App. 2002). However, a sperm donor agreement does not govern the relationship between lesbian co-parents. Wakeman v. Dixon, 921 So. 2d 669, 670 (Fla. 1st Dist. Ct. App. 2006); see also infra text accompanying notes 135-44.

144 " $[\mathrm{A}]$ ny man who has reason to believe that he is the father of a child . . . may bring proceedings in circuit court . . . to determine the paternity of the child when paternity has not been established by law or otherwise." FLA. STAT. § 742.011 (2006).

145 FLA. STAT. § 382.013(2) (2006).

146 FLA. STAT. § 63.054 (2006).

147 The strategy of constructing a legal relationship through support and property agreements, contracts, wills and health care surrogacy documents has been largely successful for gay and lesbian couples in areas other than child custody. In Posik v. Layton, a Florida appellate court upheld anterelationship support agreement between a cohabitating lesbian couple, noting that such agreements were valid between unmarried adults "unless the agreement is inseparably based upon illicit consideration of sexual services.” 695 So. 2d 759, 762 (Fla. 5th Dist. Ct. App. 1997). 
This has been especially true with respect to lesbian relationships in which the couple together decides to engage in family creation using artificial insemination. However, contractual agreements cannot govern child custody arrangements in Florida. Consider the case where two women, Mary Wakeman (an attorney) and Dené Dixon, eight years into their relationship, jointly entered into an agreement with a sperm donor. ${ }^{148}$ The contract identifies both women as recipient, mother and co-parent, and the donor surrenders all parental rights to the women. The language of the contract suggests that both women were inseminated. More importantly, it provided that Wakeman and Dixon intended to co-parent any children resulting from the insemination, and that should one of them pre-decease the other or become unable to care for the child, that the child should remain with the other woman.

Only Dixon became pregnant. Following the child's birth, the women entered into an agreement in which they acknowledged that the decision to have a child was a joint decision, that Wakeman agreed to financially support the child, and that extensively described Wakeman's relationship with the child as one of a de facto parent who maintained a psychological parenting relationship with the child. The agreement also foretold of the possibility that the couple would dissolve their relationship at some point in the future, and expressed their mutual intent to jointly share in raising the child even in that event. ${ }^{149}$

Two years later, Dixon again became pregnant through artificial insemination and using a similar donor agreement. Following that birth, another co-parenting agreement was signed by the women. ${ }^{150}$ In addition to the agreements, Dixon and Wakeman executed a domestic partnership, which permitted Wakeman to put Dixon and the two children on her health insurance policy. ${ }^{151}$ Wakeman was also designated as the pre-need guardian of the children, had authority to make medical and dental decisions, and was the named health care surrogate and attorney for Dixon. ${ }^{152}$ Despite these multiple formal arrangements, when their relationship ended after

148 The decision describes the document between the two women and the sperm donor as an agreement and not as a contract. Wakeman v. Dixon, 921 So. 2d 669, 670 (2006). It may well be that the donor received no consideration for his contribution of sperm, and that the term "agreement" is technically more accurate. However, consideration is unlikely to have any bearing on the legal sufficiency of any agreement regarding parental responsibility and child custody under Florida law. See discussion supra note 125.

149 Wakeman, 921 So. 2d at 670. See also Music v. Rachford, 654 So. 2d 1234 (Fla. 1st Dist. Ct. App. 1995) (finding that Florida law does not permit non-parents to seek visitation or custody).

150 Wakeman, 921 So. $2 \mathrm{~d}$ at 670.

151 Id. at $670-71$.

152 Id. at 670 . 
nearly 15 years, Dixon refused to honor any of her commitments and refused to allow Wakeman to share in the children's lives. ${ }^{153}$

Wakeman's efforts to enforce the agreements before the Florida courts failed because Florida's courts claim not to possess the "authority to compel visitation between a child and a person who is not a parent." 154 In Beagle v. Beagle, the Florida Supreme Court ruled that grandparents are third parties who cannot enjoy child visitation rights with minor children "absent evidence of a demonstrable harm to the child." 155 This threshold places an even greater burden on the non-parental party seeking visitation than the "best interests of the child." Because the state may not interfere with the constitutionally-protected privacy interests of a parent unless it can establish a compelling interest, the non-parental party --be they a grandparent, relative, or lesbian co-parent -- must show that "a substantial risk of significant harm to the child exists." that is unlikely to be met when a parent is considered "fit" by even the most minimal standard; it demands, in essence, a dependency hearing. Thus, claims by non-parents to being a child's de facto parent, a co-parent, a psychological parent, and even a claim that the child will be psychologically damaged by severing ties to the non-parent will fail in Florida courts. Nonparents can only hope that their ex-partner, the child's biological parent, will honor her agreements and act in the best interests of their children.

The increasing incidences of gay family dissolutions involving children, prompted one judge in the Wakeman case to call on the state legislature to "address the needs of the children born into or raised in these nontraditional households when a break-up occurs." of the children and the growing number of women using assisted reproduction, Judge Van Nortwick argues that the dissolution of a gay family can be just as damaging to a child as the dissolution of a marital relationship. ${ }^{159}$ His petition, however, has fallen on deaf legislative ears.

153 Id. at 671 .

154 Id.

155678 So. 2d 1271, 1276 (Fla. 1996). The mother and father are assumed to be the first and second parties.

156 Id. (citing Padgett v. Dep't of Health \& Rehab. Servs., 577 So. 2d 565, 571 (Fla. 1991)). Florida's explicit constitutional guarantee of privacy in Article 1, Section 23 of the Florida Constitution affords its citizens more rights against the state than those privacy rights found in the federal Constitution. Winfield v. Div. of Pari-Mutuel Wagering, 477 So. 2d 544, 548 (Fla. 1985).

157 See, e.g., D.E. v. R.D.B., 929 So. $2 d 1164$ (Fla. 5th Dist. Ct. App. 2006) (denying ex-partner's dependency petition claiming children would be psychologically impaired by separation); Kazmierazak v. Query, 736 So. 2d 106 (Fla. 4th Dist. Ct. App. 1999) (denying psychological parent claim for visitation or custody); Music v. Rachford, 654 So. 2d 1234 (Fla. 1st Dist. Ct. App. 1995) (denying co-parent claim based on agreement for visitation or custody).

158 Wakeman, 921 So. 2d at 674 (J. Van Nortwick, specially concurring).

159 Id. at 675. 
While lesbians enjoy the benefits of a womb and the possibility of carrying their own child to birth, biology has placed gay men at a great disadvantage in parenting as they must rely on the good will of women who are, first, willing to carry their children through to child birth, and second, to either surrender the children to the father's sole custody or share custody of the children. ${ }^{160}$ For gay men who live in a state where adoption may be foreclosed to them, the services of a surrogate may be the only avenue to family building.

\section{Surrogacy}

Surrogacy provides yet another method by which gay men and lesbians may start their families. At its most basic, surrogacy is simply a service in which a woman agrees to carry a child to term on behalf of someone else. ${ }^{161}$ Two types of surrogacy arrangements are possible: traditional and gestational. In a traditional surrogacy agreement, the birth mother agrees to be artificially inseminated with the sperm of a man who desires to father a child. The surrogate provides not only her womb, but also her egg, and is, thus, biologically related to the child. The surrogate agrees to surrender the child following its birth to the biological father and to voluntarily terminate her own parental rights. Gestational surrogacy is quite different in that the surrogate has no biological connection to the child. The birth mother agrees to carry to term an embryo that is conceived outside the womb using the egg of another woman, and to surrender the child following birth to the contracting parents, who may or may not be related to the child. Gestational surrogacy is the most common surrogacy method employed in the United States today. ${ }^{162}$

Surrogacy came onto the national legal landscape in the late 1980s, in the case of In re Baby $M$, a highly-publicized New Jersey case that declared surrogate contracts illegal in that state. ${ }^{163}$ Baby Melissa was conceived and born as a result of a traditional surrogacy arrangement; the surrogate mother, a married woman, entered into a contract to be artificially insemi-

160 It seems appropriate to note here the recent announcement of a pregnant "man." Born a woman, Thomas Beatie underwent testosterone treatments and some surgical transformations towards gender reassignment, but did not have his reproductive organs removed. He is recognized as a man under Oregon law, and is legally married to a woman who is unable to bear children. The pregnancy was achieved through home-based artificial insemination by donor sperm. Russell Goldman, It's My Right, Pregnant Man Tells Oprah, ABCNEws, Apr. 3, 2008, available at http://abcnews.go.com/Health/ story?id=4581943\& page $=1$ (last visited April 6, 2008).

161 American Society for Reproductive Medicine, Third Party ReProduction: A Guide FOR PATIENTS 3 (2006), available at http://www.asrm.org/Patients/patientbooklets/thirdparty.pdf.

162 Id. at 3.

163 In re Baby M, 537 A.2d 1227, 1264 (N.J. 1988); see also Carol Sanger, Developing Markets in Baby Making: In the Matter of Baby M, 30 HARV. J.L. \& GENDER 67 (2007) (exploring the personal and economic interest behind the case). 
nated with sperm from a married man, and agreed to surrender the baby upon birth to the natural father and his wife. ${ }^{164}$ When the surrogate refused to surrender the child to the natural father and his wife and ultimately fled the state with the child, the case became the focus of national media attention. Apprehended in Florida, the child and surrogate were returned to New Jersey where a protracted legal battle found its way to the Supreme Court of New Jersey. That court refused to recognize and enforce the surrogacy agreement, noting that such contracts went against the public policy of the state. ${ }^{165}$ A mother could not contract away or sell her rights to a child. ${ }^{166}$ In the end, the court took a Solomonic approach, awarding custody of Baby M to the natural father with visitation by the natural mother, who retained her parental rights. ${ }^{167}$ The intended mother was awarded no legal recognition by the court. ${ }^{16}$

The facts of this particular case prompted state legislatures and national lawmakers to recognize the growing vacuum in reproductive technology policy that was resulting from the increased use of surrogates in family creation. The National Conference of Commissioners on Uniform State Laws (NCCUSL) responded to the Baby M case in late 1988, with the Uniform Status of Children of Assisted Conception Act (USCACA). ${ }^{169}$ The Act offered state legislatures two options: prohibit surrogacy outright, or allow it under stringent regulations. ${ }^{170}$ While the Act failed to get much attention from the states, the NCCUSL subsequently included surrogacy in the Uniform Parentage Act (UPA) of 2000, and limited surrogacy arrangements to married couples. ${ }^{171}$ That restriction was eliminated in the 2002 revision of the UPA. ${ }^{172}$ Today, about one-third of the states have any legislation on surrogacy, and that ranges from outright prohibition to strict regulation. $^{173}$

Florida addressed traditional surrogacy in 1988, calling it "pre-planned adoption" and enacting it within the scope of the state's adoption statute. ${ }^{174}$ Five years later, in 1993, the state adopted legislation regulating gestational

164 In re Baby M, 537 A.2d at 1235.

165 Id. at 1249.

166 Id. at 1242.

167 Id. at $1234-35$.

168 Id.

169 Richard F. Storrow, Rescuing Children From the Marriage Movement: The Case Against Marital Status Discrimination in Adoption and Assisted Reproduction, 39 U.C. DAVIS L. REV. 305, 31415 (2006). See also UNIF. STATUS of CHILDREN OF Assisted CONCEPTION ACT, available at http://www.law.upenn.edu/bll/archives/ulc/fnact99/uscaca88.htm.

170 Storrow, supra note 169 , at 315.

171 Id.

172 Id.

173 Richard A. LORD, BARGAINS TENDING TO CORRUPTION OR IMMORALITY, 7 WiLlistON ON CONTRACTS $\S 16: 22$ (4th ed. 2007).

174 Fla. Laws 1988, c. 88-143, § 1, codified at FLA. STAT. § 63.213 (2006). 
surrogacy. ${ }^{175}$ Provisions for gestational surrogacy appear in Florida's statutes on "Determination of Parentage." While surrogacy laws have simply not been litigated in Florida's courts, there is an open question as to whether gestational surrogacy, the optimal avenue of reproduction for gay men, is available to anyone other than married couples in Florida. For gay men, surrogacy is typically the only means of fathering a child who is genetically their own. While lesbians might also employ the services of a surrogate, it is more likely that they would use artificial insemination as a familycreation strategy, if at all possible. ${ }^{176}$

\section{Traditional Surrogacy}

Traditional surrogacy is treated under the rubric of pre-planned adoptions in Florida even though no "adoption" actually takes place when the intended father (gay or heterosexual) is both the sperm donor and biological father, and there is no "intended mother." In a traditional surrogacy, an agreement is crafted between a "volunteer mother" and an intended parent (or parents), the volunteer is inseminated, and carries the resulting fetus to birth. Following birth, the surrogate voluntarily terminates her parental rights and responsibilities in favor of the intended parent. ${ }^{178}$ Florida law requires that these preplanned adoption agreements include specific acknowledgements by the parties that include the statutory requirements that either party can terminate the agreement at any time, that the "volunteer mother" has the right to rescind the agreement within 48 hours after birth, that the "volunteer mother" will assume paternal rights if the agreement is terminated, and that an intended father, who is also the biological father, assumes full parental rights for the child even if the agreement is terminated. $^{179}$ That either party can terminate the agreement prior to birth, and that the surrogate can rescind the agreement up to 48 hours following birth, imposes a heightened risk for all parties to a pre-planned adoption or traditional surrogacy.

Notably, the pre-planned adoption agreement seems to embrace the fact that a single person - male or female - can enter into a traditional surrogacy agreement with the volunteer mother. The introductory language refers to "individuals" entering an agreement, and the definitions include

175 Fla. Laws 1993, c. 93-237. § 2, codified at FLA. STAT. § 742.13-16 (2006).

176 As discussed below, traditional surrogacy is especially subject to the risk that the birth mother will opt not to surrender the child. See supra text accompanying notes 165-176.

177 FLA. STAT. $\$ 62.213$ (2006).

178 When an intended mother is contemplated by the agreement, the volunteer mother would also consent to the child's adoption. FLA. STAT. § 62.213(1)(b) (2006).

179 The statute requires additional acknowledgements related to monetary compensation to the volunteer mother; her consent to medical care, treatment and adherence to medical instructions; and issues involving disability or impairment to the child. FLA. STAT. § 62.213(2)(a-i) (2006). 
"intended father" and "intended mother" without any indication that there must be one of each or even that if there is an intended mother and father, that they be a married couple. Furthermore, the statutory definitions of an intended father and intended mother specifically note that a biological relationship to the child is not required. ${ }^{180}$ Thus, the preplanned adoption agreement could encompass an arrangement wherein a woman agrees to be artificially inseminated by sperm from an unknown donor, and upon the child's birth, voluntarily terminates her parental rights in favor of a single man, a single woman, or a married or unmarried couple. ${ }^{181}$

On its face, the statute permits gay men and lesbians to employ traditional surrogacy as a method of family creation. But preplanned adoption agreements are not optimal for gay men and lesbians in Florida. First, preplanned adoption arrangements are subject to review and approval by a court, and "compliance with other applicable provisions of law." case of a preplanned adoption agreement in which the intended parent is not biologically related to the child, the adoption is clearly subject to the statutory ban on homosexual adoptions. ${ }^{183}$

The statutory language that directly addresses the rights and responsibilities of "the intended father who is also the biological father" suggests that the preplanned adoption arrangement may be subject to court approval "pursuant to the Adoption Act," the Act which also includes the homosexual adoption ban. ${ }^{184}$ However, this provision is directly at odds with Florida law governing unmarried biological fathers and general paternity claims. ${ }^{185}$ A gay man who is biologically related to a child born to a surrogate and who entered into a preplanned adoption agreement is not "adopting" the child. In fact, the parentage statute specifically excludes fathers who have executed a preplanned adoption agreement from the provision that requires sperm donors to relinquish their parental rights and responsibilities. ${ }^{186}$ Given that the intended father is the biological father, entitled to recognition under Florida law as the father of the child, to refer to court approval and the Adoption Act appears incongruous. A gay man, biologically the father of a child born to a surrogate, must merely assert his paternity to be recog-

180 Fla. STAT. § 62.213(6)(d-e) (2006).

181 Nothing in the language of the statute requires that the intended parents of a preplanned adoption agreement be married. FLA. STAT. $§ 63.213$ (2006).

182 FLA. STAT. $\$ 63.213(1)$ (a) (2006).

183 FLA. STAT. $\$ 63.042(3)$ (2006).

184 "That an intended father who is also the biological father acknowledges that he is aware that he will assume parental rights and responsibilities . . . if the agreement is terminated . . or if the planned adoption is not approved by the court pursuant to the Florida Adoption Act." FlA. STAT. $\$ 63.213$ (2)(d) (2006).

185 FLA. STAT. $§$ 63.053-054 (2006); FLA. STAT. § 742.011 (2006).

186 FLA. STAT. $\$ 742.14$ (2006). 
nized as a father under Florida law. The ban on homosexual adoptions in this case has little relevance.

Traditional surrogacy arrangements are typically avoided by the gay community for other, more significant reasons. ${ }^{187}$ The risks involved in a traditional surrogacy arrangement can be more costly than just the monetary arrangements outlined in the preplanned adoption agreement, especially to gay men. Consider a volunteer surrogate who changes her mind and decides to keep the child; she can burden the biological father with child support payments and an unwanted relationship (with the surrogate mother) for 18 or more years. As she is both the birth mother and the biological mother, her legal rights to the child are on par with those of the biological father, and given courts' propensity to award child custody to mothers over fathers, she may be awarded primary custody.

Because traditional surrogacy is fraught with legal complications rooted in the biological nexus between the surrogate and child, gestational surrogacy is a safer alternative for most people seeking to create a family, be they gay, lesbian or heterosexual. ${ }^{188}$ This may be true even in the face of serious legal questions regarding the enforceability of such contracts for unmarried couples and single persons under Florida law.

\section{Gestational Surrogacy}

A gestational surrogacy arrangement is one in which the surrogate becomes pregnant through the implantation of an embryo, which resulted from the in vitro fertilization of a donor egg and sperm. ${ }^{189}$ The surrogate carries and births the child, and then surrenders the child to the contractual parents, who usually have genetic ties to the child. ${ }^{190}$ The surrogate, as a party to a contract, simply provides a service -- carrying a child through birth -- to the other contracting party. She has no genetic connection to the child whom she has birthed. As in traditional surrogacy, Florida law permits the surrogate to be compensated for all "living, legal, medical, psychological and psychiatric expenses" related to the pregnancy. ${ }^{191}$ However, unlike traditional surrogacy, the contracting parties do not have a right to unilaterally terminate their agreement, and custody immediately transfers

187 A pre-planned adoption agreement might, however, provide a fallback position for a gay man who engages the services of a gestational surrogate in the event of a default. See infra p. 50.

188 Sanger, supra note 163, at n. 56 (reporting that thirty percent of reproductive clinics in the United States offer only gestational surrogacy).

189 The first successful in vitro fertilization took place in 1944, but embryonic transplantation was not successful until 1978. Debora L. Spar, The Baby Business: How Money, Science, And POLITICS DRIVE THE COMMERCE OF CONCEPTION 3 (2006), cited in Sanger, supra note 163, at n. 57. It should be noted that gestational surrogacies often result in multiple births as practice is to implant several eggs in the hope that one will mature.

190 FLA. STAT. § 742.13(5) (2006).

191 FLA. STAT. § 742.15(4) (2006). 
from the surrogate upon birth. ${ }^{192}$ Moreover, an affirmation of parental status can be obtained from the courts within three days after birth and it does not follow traditional adoption processes. ${ }^{193}$ The only provision that potentially grants the surrogate parental rights and responsibilities would come into effect if the child is not genetically related to the intended parents. ${ }^{194}$ For these reasons, gestational surrogacy is the optimal of the two surrogacy arrangements. One national infertility organization has estimated that 95 percent of all surrogacy contracts today are gestational. ${ }^{195}$

Problematic for gay men and lesbians, however, is that Florida's gestational surrogacy statute is written such that gestational surrogacy contracts are available only to married couples. ${ }^{196}$

(1) Prior to engaging in gestational surrogacy, a binding and enforceable contract shall be made between the commissioning couple and the gestational surrogate. A contract for gestational surrogacy shall not be binding and enforceable unless the gestational surrogate is 18 years of age or older and the commissioning couple are legally married and are both 18 years of age or older. ${ }^{197}$

A commissioning couple is defined as the "intended mother and father of a child who will be conceived by means of assisted reproductive technology using the eggs or sperm of at least one of the intended parents."198 Additional provisions in the statute require that the commissioning couple may only enter a gestational surrogacy contract when, "within reasonable medical certainty" as certified by a physician, the intended mother cannot carry a child to term, would be at physical risk should she become pregnant, or that a pregnancy would risk the health of the fetus. ${ }^{199}$ Because Florida's gestational surrogacy statute was enacted in the early 1990s, it has not benefited from any of the reforms urged by the National Conference of Commissioners on Uniform State Laws with the revisions to the Uniform Parentage Act. Instead, Florida's statute is rooted in the now-defunct Uni-

192 FLA. STAT. § 742.15(3)(d-e) (2006).

193 FLA. STAT. $\$ 742.16(1)(2006)$.

194 FLA. STAT. $\$ 742.15(3)(\mathrm{e})$ (2006). Generally, surrogates contractually agree to refrain from normal sexual relations during implantation efforts in order to minimize the possibility that the pregnancy and child carried to term is the surrogate's biological offspring and not the developed implanted embryo.

195 Sanger, supra note 151, at notes 43, 56 (citing Fact Sheet 56: Surrogacy (Gestational Carrier) RESOlVE: THE NATIONAL INFERTILITY ASSOCIATION, at 2 (2004)).

196 For a discussion of the heterosexual-only marriage movement's influence on both adoption and assisted reproduction techniques, such as surrogacy, see Richard F. Storrow, Rescuing Children from the Marriage Movement: The Case Against Marital Status Discrimination in Adoption and Assisted Reproduction, 39 U.C. DAVIS L. REV. 305 (2006).

197 FLA. STAT. $\$ 742.14(1)(2006)$.

198 FLA. STAT. $\$ 742.13(2)(2006)$.

199 FLA. STAT. § 742.15(2) (2006). 
form Status of Children of Assisted Conception Act, passed in the wake of the Baby M case. ${ }^{200}$

The Florida statute is textually clear that a contract for gestational surrogacy will not be enforced if a married couple is not a party to it. Thus, a contract between a surrogate and a single man, a single woman, or an unmarried couple, regardless of sexual orientation, would not be "binding or enforceable" in a Florida court in the event that one of the parties fails to perform under the contract. However, there are unmarried Floridians, especially gay men, who have virtually no other avenues for family building, who are intent on becoming parents, and are willing to risk the unenforceability of a gestational contract to do so. As long as all parties believe the contract is enforceable and no one defaults, little attention will be given by a court to the surrogate's voluntary termination of parental rights, and the declaration of parentage of the intended father. What a Florida court will do in the event of a default on a gestational surrogacy contract is the more interesting legal question.

\section{a. Gestational Surrogacy Contractual Defaults: Whither the Law?}

Determining the parentage of a child conceived through gestational surrogacy when there is a contractual default may, at first glance, look much like a contractual default over the sale of a car or piece of real estate, but it is significantly different given the fundamental interests and rights not only of the contractual parties, but of the child. Declaring a contract void, $a b$ initio, cannot relieve the court from its duty to resolve disputed parentage issues stemming from a gestational surrogacy. If a gestational surrogate defaults and the contract is void, the court must fall back on statutory principles of parentage to determine not only the identity of the mother and father, but to make custody and support decisions. Such a dispute would be one of first impression in Florida; there are no reported cases involving defaults by gestational surrogates in this state. ${ }^{201}$

The legal issues central to a surrogacy dispute, especially in gestational surrogacy cases, are not the same as those found at the heart of child custody disputes. ${ }^{202}$ Custody battles generally involve parties who are both the legal and natural parents of a child, equal before the law with regard to their rights and responsibilities to the child. ${ }^{203}$ These questions are resolved

200 See supra text accompanying notes 157-59.

201 The validity of surrogacy agreements and the constitutionality of surrogacy legislation has been examined by at least a third of the states' courts. California courts have, perhaps, been the most active on surrogacy concerns. . See generally 7 WILLISTON ON CONTRACTS § 16:22, supra note 173.

202 . A.L. Campbell, Annotation, Determination of status as legal or natural parents in contested surrogacy births, 77 A. L. R.5TH 567 (2000).

203 But see the earlier discussion regarding child custody issues and non-parents when gay coparents dissolve their relationships. See supra text accompanying notes 135-47. 
by determining which parent should retain custody by applying a "best interests of the child" standard. ${ }^{204}$ Gestational surrogacy disputes may require the answer to a preliminary and more fundamental question, "Who is the parent?"

Courts typically employ one of three tests, or a combination thereof, to determine parentage in surrogacy cases: the intent of the parties, the genetics of the parents and child, or the identity of the birthing parent. ${ }^{205}$ The California Supreme Court employed the intent-of-the-parties approach in the seminal case of Johnson v. Calvert, finding that the intended mother and father were both the natural and legal parents of a child born using their egg and sperm, and rejecting the surrogate's maternal claim based on birth. ${ }^{206}$ The Johnson approach was subsequently applied in In re Marriage of Buzzanca, a California case in which neither of the intended parents nor the surrogate mother were genetically related to a child who was conceived through the donation of both anonymous eggs and sperm. ${ }^{207}$ Rather than a dispute between the surrogate and the intended parents, Buzzanca involved the divorce of the intended parents. The intended father denied paternity and the intended mother sought child support from her soon-to-be exhusband. ${ }^{208}$ Rejecting the trial court's finding that the child had no lawful parents, the Buzzanca Court ruled that the intended parents were the lawful parents even though they were not genetically related to the child. ${ }^{209}$

Employing a different approach, an Ohio court relied on genetics over birth and intent. In ruling that the natural (and intended) parents were the legal parents, the court left open the possibility that a claim by the birth mother would be upheld only if the natural parents disclaimed the child and the surrogate desired the child. ${ }^{210}$ Other courts also focus on genetics and gestation, holding that the genetic connection to a child is of paramount importance in determining legal maternity. ${ }^{211}$ In J.R. $v$ Utah, a federal court declared unconstitutional Utah's surrogacy law, which was designed to discourage surrogacy arrangements by mandating that a surrogate mother is the only legal mother recognized under state law. ${ }^{212}$ The court found that Utah's statutorily-based refusal to recognize the natural parents as the legal parents of their own child, born through a surrogacy arrangement, violated the fundamental rights of the intended and natural parents to procreate. ${ }^{213}$

\footnotetext{
204 . L.J. Harris, L. E. Teitelbaum \& J. CARbone, FAmily LaW 622-60(2005).

205 Campbell, supra note 202, at 567; L. H. Dietz, Parent and Child, 59 AM. JUR. 2D §3 (2007).

206 Johnson v. Calvert, 851 P.2d 776, 787 (1993).

207 In re Marriage of Buzzanca, 61 Cal. App. 4th 1410 (4th Dist. 1998).

208 Id. at 1412.

209 Id.

210 Belsito v. Clark, 644 N.E.2d 760 (Ohio Com. Pl. 1994).

211 See, e.g., Culliton v. Beth Israel Deaconess Med. Ctr., 756 N.E.2d 1133 (Mass. 2001).

212 J.R. v. Utah, 261 F. Supp. 2d 1268 (D. Utah 2002).

213 Id. at 1290.
} 
How a gay man or any person other than a married commissioning couple would fare in a dispute with a gestational surrogate in Florida depends, in large part, on how the court would approach its analysis of parentage, which provisions of Florida law it would favor, and the degree to which the surrogacy contract serves an evidentiary function in the proceedings. It would also depend on the manner in which the case is presented to the court: as a claim by an intended and natural single parent, as an issue in a divorce action, or even as a petition by a surrogate who, although biologically unrelated to the child, seeks judicial relief from maternal responsibilities due to a default by a natural parent. Establishing paternity and disestablishing maternity would be core to any decisions an intended gay parent.

\section{b. Establishing Paternity}

The most probable litigation scenario in Florida would be sparked by a gestational surrogate's unwillingness to surrender physical control of the child, prompting the intended father to file suit to establish paternity and seek custody. Thus, the first issue for the court, absent the unenforceable surrogacy contract, would be to identify the child's father. How a Florida court approaches paternity may vary depending upon whether the surrogate is married at the time of the child's birth. ${ }^{214}$ Florida's parentage laws provide that if the mother is married at the time of a child's birth, her husband is presumptively the father of the child, "unless paternity has been determined otherwise by a court of competent jurisdiction." ${ }^{215}$ When a married woman gives birth, Florida law requires her husband to be named as the father on the child's birth certificate. ${ }^{216}$ This presumption of marital fatherhood is "one of the strongest rebuttable presumptions known to the law," but it is rebuttable by either the husband or the wife's paramour. ${ }^{217}$

State law also establishes an irrebuttable presumption that a child conceived within wedlock by artificial or in vitro insemination, by a donated

\footnotetext{
214 A husband may also be presumed to be the father if the marital couple engaged in premarital relations during the possible period of conception. See, e.g., Dep't of Health and Rehab. Serv. v. Privette, 617 So. 2d 305 (Fla. 1993); Eldridge v. Eldridge, 16 So. 2d 163 (Fla. 1944); Blitch v. Blitch, 341 So. 2d 251 (Fla. 1st Dist. Ct. App. 1976).

215 Fla. STAT. § 382.013(2)(a) (2006). See also, Dep't of Revenue ex rel. Preston v. Cummings, 871 So. 2d 1055, 1059 (Fla. 2d DCA 2004) (finding that marital parties have a legal duty to support child born of the marriage); G.F.C. v. S.G., 686 So. 2d 1382, 1385 (Fla. 5th DCA 1997) (protecting legal father's rights against third party claims); Hess v. Hess, 466 So. 2d 1179, 1180 (Fla. 3d DCA 1985) (finding that presumption of legitimacy may prevent child's mother from contesting legal father's parental rights).

216 FLA. STAT. $\$ 382.013(2)$ (a) (2006).

217 Eldridge v. Eldridge, 16 So. 2d 163, 163 (Fla. 1944); see also Dep't of Health \& Rehab. Servs. v. Privette, 617 So. 2 d 305 (Fla. 1993) (emphasizing best interests of the child in disputes between legal and natural fathers).
} 
egg, or by preembryo is the child of the husband and wife, "provided that both parties have consented in writing" to the reproductive technology used, except in the case of gestational surrogacy. ${ }^{218}$ If the contract of gestational surrogacy is void and unenforceable, the gestational-surrogacy exception to the irrebuttable presumption should not be recognized by the court. However, it is common practice in gestational surrogacy arrangements to require husbands of married surrogates to sign a separate denial of consent to the reproductive technique in order to affirmatively void the irrebuttable presumption that the resulting child is conceived by the married couple. $^{219}$ In the event that a gestational surrogacy arrangement soured in Florida, the husband's written denial of consent independent of the surrogacy contract and standing alone, should provide evidence sufficient to undermine the irrebuttable presumption in favor of the husband, allowing the natural or biological father to advance his paternity interests against the surrogate's husband now-rebuttable presumption that he is the father of the child.

Florida law allows "any man who has reason to believe that he is the father of a child" to bring an action in circuit court to determine paternity. ${ }^{220}$ The state, ever interested in securing child support from putative fathers, also welcomes affidavits and voluntary acknowledgments of fatherhood. ${ }^{221}$ Thus, a father in a failed gestational surrogacy arrangement could simply file an affidavit or voluntarily acknowledge paternity. If the surrogate disputes his fatherhood, as she may under Florida law, state law provides that a court may, on its own motion, order scientific testing of the mother, child, and any alleged fathers to establish paternity. ${ }^{222}$ Courts may also order sci-

218 Fla. STAT. $\$ 742.11(\mathrm{a}-\mathrm{b})$ (2006).

219 See Sanger, supra note 163, at 80, n. 60 (reporting on Baby M, Rick Whitehead signed denial of consent).

220 FLA. STAT. $§ 742.011$ (2006). The rule in Privette, however, permits the legal father (the husband of the surrogate) to be heard and would require the court to establish that the paternity claim is factually accurate, brought in good faith, supported by reliable evidence, and that the child's better interests would be served if the child is determined not to be the legitimate child of the marriage. Dep't of Health and Rehab.Servs. v. Privette, 617 So. 2d 305, 307 (Fla. 1993). In Daniel, the Florida Supreme Court distinguished Privette as a question of legitimacy over paternity. Daniel v. Daniel, 695 So. 2d 1253, 1255 (Fla. 1997). See, also, R. Thomas Corbin and Rana Holz, Distinguishing Legitimacy From Paternity: Has Legitimacy Become A Label Without Substance Under Florida Law? 73 FLA. B. J. 57 (1999).

221 The state charges the Department of Revenue with seeking out putative fathers, establishing their paternity, requiring them to pay support to the child's mother, and in some cases, repay the state for any child welfare and medical assistance provided. FLA. STAT. $\$$ 409.256(e) (2006). Most of the cases involving scientific paternity testing stem from Department of Revenue actions. See, e.g. Dep't of Revenue ex rel. Freckleton v. Goulbourne, 648 So. 2d 856 (Fla. 4th DCA 1995); Dep't of Revenue ex rel. Gardner v. Long, 937 So. 2d 1235 (Fla. 1st DCA 2006). Signed voluntary acknowledgements of paternity are specially favored by Florida law, and enjoy a favored status if uncontested in that after 60 days, the acknowledgement creates a limited rebuttable presumption of paternity that can only be challenged on the basis of fraud, duress, or material mistake of fact. FLA. STAT. § 742.10(1\&4) (2006).

222 FLA. STAT. § 742.12 (1) (2006). 
entific testing at the request of a party who provides a sworn statement or written declaration alleging paternity "setting forth facts establishing a reasonable possibility of the requisite sexual contact between the parties."223 This latter provision provides little force to the intended father in a gestational surrogacy arrangement as he cannot substantiate "the requisite sexual contact" between the parties.

Also problematic for the intended father in a failed gestational surrogacy arrangement is a statutory provision that might treat the intended father as nothing more than a sperm donor with no rights to the child. Florida Statute s. 742.14 states that the "donor of any ... sperm . . other than the commissioning couple or a father who has executed a preplanned adoption agreement under s. 63.212, shall relinquish all maternal or paternal rights and obligations with respect to the donation or the resulting children." 24 A Florida court might cut off the intended father's paternity claim, reasoning that without the contract the father is merely a sperm donor, much like the biological father in Lamaritata v. Lucas. ${ }^{225}$

In Lamaritata, the court ruled that the biological father was not a parent and rejected his claim that he and the biological mother were a commissioning couple under Florida's gestational surrogacy statute. ${ }^{226}$ In that case, however, the biological father had signed a contract agreeing that if childbirth resulted, he would have no parental rights or obligations. He affirmatively surrendered his parental rights; thus, the biological father was more like a sperm donor than an intended father. Of note in the Lamaritata decision is the court's recognition that the statute fails to define "sperm donor." Relying on the text of the contract, which refers to the biological father only as a "donor," and sperm as "the only donation required of him," and the state statute, the court concludes that the biological father is only a sperm donor and not a parent. ${ }^{227}$

Whether a court would come to a similar conclusion in the case of an unenforceable surrogacy contract depends on whether the court would be willing to distinguish the affirmative waiver of parental rights by the sperm donor in Lamaritata from the biological father's intent to parent as evidenced - albeit, not enforced - by the surrogacy contract and, the surrogate's husband's denial of consent, in the case of a married surrogate. A court that accepts this distinction would be likely to permit the intended father to substantiate his paternity through scientific testing. ${ }^{228}$ But gaining

223 FLA. STAT. § 742.12 (2) (2006).

224 FLA. STAT. $\$ 742.14$ (2006).

225 Hersey v. State, 823 So. 2d 316 (Fla. 2nd Dist. Ct. App. 2002).

226 Id. at 318-19.

227 Id.

228 Under Florida Statute s. 742.011 (2006), "any man who has reason to believe that he is the father of a child . . . may bring proceedings in the circuit court." 
paternal recognition would be only half of the battle for an intended parent facing an unenforceable surrogacy contract. The other half of the fight would be to deny the surrogate any rights or recognition as the child's mother, and this may be the more difficult hurdle for a gay father.

\section{c. Dis-establishing Maternity}

Historically, parentage questions raised only paternity issues-who is the father? Florida's law, like those of many states, has not evolved to consider the possibility that a child born to a woman may not be that woman's biological offspring. Florida does not even define "mother" in its parentage statutes. $^{229}$ In fact, the clearest statement of Florida's view on maternity dates back to 1934, when the Florida Supreme Court found, "A wife is not permitted to deny the parentage of children born during wedlock. She cannot repudiate their legitimacy. That right belongs only to the father, because maternity is never uncertain. She may only contest the identity of the child." ${ }^{230}$ Florida law does not address the status of the mother nor does it explicitly establish that there is a presumption --rebuttable or irrebuttable -that the birth mother is the legal mother of a child. However, public records laws mandate that a record of live birth or birth certificate "must be as to the child's birth parents unless and until an application for a new birth record is made" under the adoption statute. ${ }^{231}$

An unanswered question in this situation is whether a court would even entertain proceedings to determine "maternity" when there is no question that an identifiable woman gave birth to the child in question. While Florida law addresses assumptions of parentage with regard to married couples, that a child born to during marriage is presumed to be the child of both the mother and father, it does not explicitly make a presumption that a child born to a woman is that woman's child. But Florida law requires that information on a birth certificate be given as to the child's "birth parents" (even if there is a pending adoption), which may further complicate future proceedings to have the surrogate removed as the child's mother. ${ }^{232}$ Finally, Florida law specifically provides only for paternity proceedings; it makes no mention in any statute of determinations of motherhood.

Whether a court would read the jurisdictional statute that charges circuit courts with making paternity determinations as granting jurisdiction over maternity issues depends largely on the reading of the individual judge to whom the case is assigned. A strict reading of the law would forestall

229 But see, e.g., TENn. CodE ANN. § 36-2-302(4) (2001) (defining mother as the biological mother of a child born out of wedlock.)

230 Gossett v. Ullendorff, 154 So. 177, 181 (Fla. 1934) (distinguishing between ruling in probate case that widow who disclaimed children had unclean hands).

231 FLA. STAT. § 382.013(1)(g) (2006).

232 Id. 
nearly every challenge to maternity in Florida. The statute permits only three parties to bring paternity proceedings: 1) a woman who is pregnant or has a child, 2) any man who has reason to believe that he is the father of a child, or 3) any child. ${ }^{233}$ The statute also defines when paternity proceedings may be brought as "when paternity has not been established by law or otherwise." 234 A court may find that a man simply cannot use the law to challenge the legal interests of a woman who, although not genetically related to the child, is the only identifiable woman that could serve as a "mother" to the child even if the natural father has already established his paternity. A court might also take a more liberal approach, recognizing that the law is outmoded and finding that the fundamental rights of a parentthe father-are at risk. Based on that reasoning, and armed with evidence in the form of the gestational contract that strongly suggests that the surrogate is not the mother of the child, a court may entertain a maternity proceeding and require a woman to establish her genetic relationship to the child.

The legal culture of Florida suggests, however, that courts are more likely to read a statute strictly, and rule in a manner that favors the "traditional" family, even in the face of non-traditional circumstances. If the egg donor is identifiable, a Florida court may be more willing to grant parentage to the biological parents of the child because a traditional family would exist. However, if the egg donor is anonymous and the natural father is a gay man, public policy preferences would likely result in the Baby $M$ compromise. The surrogate, even though genetically unrelated, would be identified as the mother along with the natural father and a custody determination would ensue. The result would look more like a preplanned adoption or traditional surrogacy. Ultimately, a Florida court would like rely on a "best interests of the child" standard and insure that a child has both a mother and father.

The manner in which a gestational surrogacy case reaches the court will also determine the type of analysis a Florida court might use. In Tennessee, an unmarried couple decided to begin a family. ${ }^{235}$ Using the eggs of an anonymous donor and the sperm of the intended father, the pre-embryos were implanted in the surrogate who was also the intended mother. She gave birth to triplets and when the unmarried couple's relationship dissolved, the birth mother/surrogate brought a paternity action against the natural father. His defense rested on the fact that the birth mother was not the genetic parent and therefore, not the legal parent with standing to file the paternity action. The Tennessee Supreme Court recognized that their

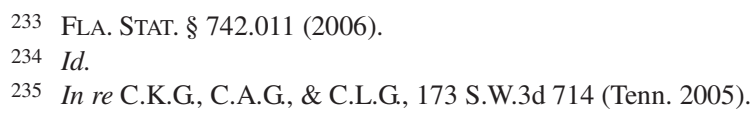


state laws simply did not "contemplate many of the scenarios made possible by recent developments in reproductive technology.", the natural father's argument, finding that the birth mother was the legal parent and awarding custody to both the natural father and legal mother, with the mother having primary custody. ${ }^{237}$

This discussion of gestational surrogacy suggests that lesbians and gay men who enter into nonbinding and unenforceable gestational surrogacy contracts in Florida should consider several actions to protect their interests in the child. First, the potential for disputes over paternity are exacerbated when the surrogate is married. Intended parents would be best served in seeking out an unmarried and experienced surrogate. ${ }^{238}$ Second, an intended father should establish paternity as soon as the pregnancy is confirmed by filing an affidavit acknowledging paternity under Florida Statute s. 742.10(1) (2006). In doing so, any challenge to the intended father's claim closes sixty days after the affidavit is filed, which is well before the child is born. ${ }^{239}$ Blood tests in utero can also provide early evidence of paternity that may support a declaration of paternity even before the child is born.

In order to avoid a court declaration that the intended father is merely a sperm donor under Florida law, the intended father may want to supplement the gestational surrogacy contract with a preplanned adoption agreement, which would be recognized under Florida law. While the preplanned adoption agreement would place the gay father back into the predicament of possibly sharing custody of his child with the surrogate, not having the agreement could result in a finding that the father is merely a sperm donor entitled to no rights under law.

Finally, the intended parents would be well-served by seeking scientific paternity and maternity testing of the fetus as early in the pregnancy as safely possible. Results that show that the surrogate is not the natural mother may later serve to persuade an open-minded court that the surrogate does not have standing to challenge paternity and to claim custody. They may also serve as the basis for a pre-birth finding of paternity and maternity. Ultimately, the existence of the results might just simply dissuade the surrogate from contesting the agreement.

In sum, a gay man or lesbian takes risks in entering into a gestational surrogacy contract in that it will likely prove unenforceable in state court.

236 Id. at 721 .

237 Id. at 733.

238 Note, however, that there is nothing that would prevent an unmarried surrogate from marrying during the pregnancy, which would effectively establish the legal presumption, albeit rebuttable, that her husband is the father.

239 The only challenges that may be raised after 60 days are those related to fraud, duress or material mistake of fact. FLA. STAT. § 742.10(4) (2006). 
On balance, however, the risks might be less than in a traditional surrogacy or preplanned adoption agreement in Florida. When gestational surrogacy arrangements are done, prospective parents are well-advised to work closely with legal counsel who have experience in this specialized practice and to select a gestational surrogate who is experienced and known to be reliable.

\section{CONCLUSION}

This Comment has closely examined the three major ways in which gays and lesbians in Florida can become parents within the contours of Florida law: adoption, artificial insemination and surrogacy. But as the historical backdrop to Florida's adoption ban suggests, there is great resistance by both politicians and the courts to embrace the liberalization of "family" in Florida. Roadblocks against lesbigay parenting in Florida are likely to remain on the public agenda until the ban on "homosexual" adoptions is reversed either by the state legislature or by the courts. Some in the state legislature have unsuccessfully introduced legislation to modify or reverse the ban. ${ }^{240}$ For example, legislation introduced in anticipation of the 2008 Florida legislative session would permit adoptions by gay men and lesbians in very limited circumstances. ${ }^{241}$ Specifically, the bill would lift the blanket ban on adoptions and permit adoptions by gays and lesbians when a court finds by clear and convincing evidence that a child, who must have resided with the person seeking to adopt, recognizes that person as the child's parent and the adoption serves the best interest of the child. ${ }^{242} \mathrm{~A}$ lesbigay adoption could also be granted if the person seeking to adopt had 1993).

241 “A Bill to Be Entitled An Act Relating to Adoption," H 45, introduced July 31, 2007, by Representative Mary Brandenburg. Parallel legislation was introduced in the Florida Senate. See, "A Bill to Be Entitled An Act Relating to Adoption," SB 200, introduced on September 6, 2007, by Senator Nan Rich. At the time of writing, the House bill had been referred to the Committee on Healthy Families and the Senate bill had been referred to the Committee on Children, Family and Elder Affairs, which was conducting public hearings across the state.

242 Id. The proposal would amend Florida Statute s. 63.042(3) (2006) by revising language, and adding subsections (a) and (b):

(3) (a) A person is not eligible to adopt under this section if that person is a homosexual, except as provided in paragraph (b) or paragraph (c).

(b) A person who is homosexual is eligible to adopt if a court finds, by clear and convincing evidence, that:

1. The child has resided with the person proposing to adopt the child;

2. The child recognizes the person proposing to adopt the child as the child's parent; and

3. The best interest of the child will be served by approving the adoption. In determining the best interest of the child, the court shall consider whether granting the child permanency in the home of the person proposing to adopt the child is more beneficial to the child's development and psychological needs than maintaining the child in temporary placement. 
been named as guardian of a minor child by the child's deceased parents, and if the last surviving parent had expressed an intention through petition under Florida's standby guardianship statute, ${ }^{243}$ recorded declaration under the state's preneed guardianship law, ${ }^{244}$ or by will or codicil that the guardian be eligible to adopt. ${ }^{245}$

Such a weakening in the adoption ban may establish the "irrationality" necessary to mount an effective equal protection challenge under state law. For now, however, the old nursery rhyme, "[f]irst comes love, then comes marriage, then comes Mary pushing a baby carriage," does not describe the lives of gay men and lesbians in Florida. While love certainly comes first in contemporary gay relationships, it is likely to be followed by the baby carriage with the hope, that someday in the future their relationships will be fully recognized by the state. Lesbigay parenting may ultimately transform public thinking on gay marriage as issues that gave rise to the common law structures of property and intestacy find their way in American courts in the context of lesbigay family matters. If the best interests of the child truly remain at the core of Florida's legal values, a child who is the son or daughter of gay men or lesbians deserves nothing less than the children of heterosexual couples.

243 FLA. STAT. $\$ 744.304$ (2006).

244 FLA. STAT. $\$ 744.3046$ (2006).

245 Id. The proposal would amend Florida Statute s. 63.042(3) (2006) to add (c):

(c) A person who is homosexual is eligible to adopt if both parents of the child are deceased and the person proposing to adopt the child is the guardian of the person of the minor as a result of:

1. A petition that has been filed by the parent or parents under s. 744.304, that names the person proposing to adopt the child as the guardian of the person of the minor, and that expresses the intent that the guardian be eligible to adopt the child;

2. A declaration that has been made by both parents or the last surviving parent, that meets the requirements of s. 744.3046, that names the person proposing to adopt the child as the guardian of the person of the minor, and that expresses the intent that the guardian be eligible to adopt the child; or

3. A designation in the last surviving spouse's will which names the person proposing to adopt the child as the guardian of the person of the minor and expresses the intent that the guardian be eligible to adopt the child. 